\title{
Alternative therapies in Staphylococcus aureus diseases
}

\author{
Julianna Kurlenda ${ }^{凶}$ and Mariusz Grinholc ${ }^{2}$ \\ 1Department of Clinical Bacteriology at the Provincial Hospital, Koszalin, Poland; 2Intercollegiate Faculty of Biotechnology, University of Gdansk \\ and Medical University of Gdansk, Department of Biotechnology, Laboratory of Molecular Diagnostics, Gdańsk, Poland
}

\begin{abstract}
Staphylococcus aureus is a common pathogen responsible for health-care-associated infections as well as community acquired ones. It is the etiological factor of a wide spectrum of infections. Therapeutic problems are caused by resistance of $S$. aureus to many antibiotics, specifically to methicillin (methicillin-resistant S. aureus, MRSA). In such cases a limited spectrum of antibiotics may be used and prolonged hospitalization is costly. Hence, there is an urgent need for the development of alternative antibiotic therapeutics. This work reviews the current knowledge concerning prospective treatment of staphylococcal diseases.
\end{abstract}

Key words: Staphylococcus aureus diseases, alternative therapies

Received: 19 May, 2011; revised: 11 January, 2012; accepted: 29 March, 2012; available on-line: 11 May, 2012

\section{BACKGROUND}

Staphylococcus aureus is a pathogen able to bypass all barriers of the host defence system as it possesses a wide spectrum of virulence factors (Feng et al., 2008; Plata et al., 2009). Despite the increasing knowledge on this subject it is still difficult to prevent or effectively treat staphylococcal infections in many cases.

Therapeutic problems are caused by infections with strains which are resistant to many antibiotics and specifically to methicillin (methicillin-resistant $S$. aureus, MRSA) (Ito et al., 2001; Ito \& Hiramatsu, 2003). Due to the wide presence of infections caused by multiresistant strains the development of new therapeutic strategies including antibiotic and alternative therapies as well as prophylaxis strategies, which are important for patients before invasive medical procedures - is a busy field of research (Grinholc et al., 2008b; Hiramatsu et al., 1997; Kampf et al., 2003; Kaiser et al., 2004; Rayner \& Munckhof, 2005; Kowalski et al., 2005; Trampuz \& Zimmerli, 2006; Livermore, 2006; Tacconelli, 2006; Karchmer, 2006; Finch, 2006; Goldstein, 2007; Witte et al., 2007).

It should be noted that problems associated with the HA-MRSA (healthcare associated MRSA) infections are related not only to their resistance to beta-lactam antibiotics but also to their lack of sensitivity towards other antibacterial drugs. According to many authors resistance among HA-MRSA to fluoroquinolones ranges from $75 \%$ to $100 \%$ of strains, gentamicin $59 \%-100 \%$, clindamycin $60 \%-100 \%$, erythromycin $71 \%-100 \%$, and trimetoprim/sulfamethoxazole $30 \%$ - 97\% of strains (Sola et al., 2002; Savas et al., 2005; Conceicao et al., 2007; Kuint et al., 2007; Huang et al., 2007; Kurlenda et al., 2007; Gonlugur et al., 2003).
As a result of the increasing percentage of infections caused by the MRSA displaying intermediate sensitivity or resistance to vancomycin, antibiotic therapy is becoming more difficult and often fails (Rayner \& Munckhof, 2005; Levy, 2005; Trampuz \& Zimmerli, 2006; Livermore, 2006; Karchmer, 2006; Finch, 2006). According to the first report in 1997 regarding the therapeutic failure of vancomycin in the treatment of infection caused by MRSA with reduced sensitivity to this antibiotic, the development of resistance towards glycopeptides, which are an important group of antibacterial drugs against multidrug resistant (MDR) HA-MRSA has become a threat (Hiramatsu et al., 1997). This is the reason for the continuing research regarding developing therapy methods alternative to the use of antibiotics. This work is an overview of the current state of knowledge based on literature from recent years and also presents the Authors' point of view.

\section{STAPHYLOCOCCUS AUREUS DISEASES}

S. aureus is a cause of local infections which can in later stages develop into systemic infections such as bacteremia and sepsis both in adults (Gottlieb et al., 2000; Priest \& Peacock, Jr., 2005; Whyte et al., 2005; Collins, 2007; Benfield et al., 2007; Desachy et al., 2007) and in children (Healy et al., 2004; Regev-Yochay et al., 2005; Kuint et al., 2007). The second group of infections caused by $S$. aureus are toxin-mediated diseases (Ladhani \& Garbash, 2005; Murray, 2005; Vayalumkal \& Jadavji, 2006; Chi et al., 2006; Kurlenda et al., 2009).

Local infections are associated with skin and soft tissue damage such as wound infections (Kalmeijer et al., 2000), skin infections (folicullitis, furuncles), cellulitis, abscesses (Ladhani \& Garbash, 2005; Vayalumkal \& Jadavji, 2006; Moran et al., 2006; Chi et al., 2006) and deep infections such as myositis (Roberts \& Chambers 2005), osteomyelitis (Smeltzer \& Gillaspy, 2000; Lew \& Waldvogel, 2004; Priest \& Peacock, Jr., 2005; Davis, 2005; Dzwonkowska et al., 2007), pericarditis (James, 2001; Browatzki et al., 2006), endocarditis (Gottlieb et al., 2000; Fowler, Jr., et al., 2005b; Chesi et al., 2006), septic arthritis (Davis, 2005), and pneumonia (Le et al., 2001; Francis et al., 2005). The device-related infections can be caused by a foreign body such as intravascular catheters (Priest \& Peacock, Jr., 2005; Collins \& Hampton, 2005; Fowler, Jr. et al., 2005a; Nowakowska et al., 2007), propylene nets (Abele-Horn et al., 2000), ventriculoperitoneal shunts

\footnotetext{
e-mail: bakteriologia@op.pl
}

Abbreviations: MDR, multidrug resistant; MSSA, ?; MRSA, methicillin-resistant S. aureus; HA-MRSA, healthcare associated MRSA; SFD, Staphylococcal Foodborne Diseases SSSS, Staphylococcal Scalded Skin Syndrome; TSS, Toxic Shock Syndrome 
Table 1. Staphylococcus aureus virulence factors

\begin{tabular}{|c|c|c|c|}
\hline Group of virulence factors & Selected factors & Genes & Clinical symptoms \\
\hline $\begin{array}{l}\text { Connected with host tissue ad- } \\
\text { hesion }\end{array}$ & $\begin{array}{l}\text { MSCRAMMs (e.g. clumping factor, } \\
\text { fibronectin-, collagen- or sialoprotein- } \\
\text { binding proteins) }\end{array}$ & $\begin{array}{l}c l f A, c l f B, f n b A, f n b B, c n a \\
s d r, b b p\end{array}$ & $\begin{array}{l}\text { Endocarditis, osteomy- } \\
\text { elitis, endoprosthesis } \\
\text { related infections }\end{array}$ \\
\hline $\begin{array}{l}\text { Responsible for } S \text {. aureus persis- } \\
\text { tence in host organism }\end{array}$ & $\begin{array}{l}\text { Biofilm (polysaccharide production } \\
\text { responsible for intercellular adhesion), } \\
\text { small colony variant, S. aureus ability to } \\
\text { persist in host cells }\end{array}$ & locus ica, hemB & Chronic infections \\
\hline $\begin{array}{l}\text { Responsible for avoiding/fight- } \\
\text { ing host immune response }\end{array}$ & $\begin{array}{l}\text { Leukocidins (e.g. Panton-Valentine leu- } \\
\text { kocidin and toxin Y), capsular polysac- } \\
\text { charides, protein A, extracellular matrix } \\
\text { binding protein }\end{array}$ & $\begin{array}{l}\text { luks-PV, lukF-PV, hlg, cap5, } \\
\text { cap8, spa, eap }\end{array}$ & $\begin{array}{l}\text { Invasive skin infections, } \\
\text { pneumonia, abscesses }\end{array}$ \\
\hline $\begin{array}{l}\text { Connected with host tissue pe- } \\
\text { netration }\end{array}$ & $\begin{array}{l}\text { Proteases, lipases, nucleases, hilaruroni- } \\
\text { dases, phospholipase C, metalloprote- } \\
\text { ases }\end{array}$ & V8, hysA, hla, plc, sepA & Tissue lessions \\
\hline
\end{tabular}

(Spanu et al., 2005), pacemarkers (Seifert et al., 2003) and different kinds of implants used in orthopedics (Hudson et al., 1999; Jarraud et al., 2002; Lew \& Waldvogel, 2004; Davis, 2005). Both device-related diseases and local infections require simultaneous occurence of many factors enabling colonization and invasion of a host tissue ( $\mathrm{Ta}$ ble 1).

Toxins are the cause of toxin-mediated diseases such as Toxic Shock Syndrome (TSS) (Chi et al., 2006; Murray 2005), Bullous impetigo, Staphylococcal Scalded Skin Syndrome (SSSS) (Chi et al., 2006; Gravet et al., 2001; Ladhani \& Garbash, 2005; Vayalumkal \& Jadavji, 2006) and Staphylococcal Foodborne Diseases (SFD) (Murray 2005; Omoe et al., 2002; Nema et al., 2007; Naffa et al., 2006; Sandhu \& Kanwar, 2004) (Table 2).

\section{CURRENT ANTIBIOTIC OPTIONS FOR TREATMENT OF S. AUREUS INFECTIONS}

Treatment of MSSA infections is not challenging as wide range of antibiotics can be used, especially $\beta$-lactam ones (including penicillins with $\beta$-lactamase inhibitors, e.g. amoxicillin/clavulanic acid) or narrow-spectrum izoxazollil penicillins resistant to staphylococcal $\beta$-lactamases (cloxacillin). Moreover, MSSA strains seem to be susceptible to other groups of antibiotics, aminoglycosides (gentamycin, amikacin), fluorochinolones (ciprofloxacin, levofloxacin), lincosamides (clindamycin), macrolides (erythromycin), tetracyclines (doxycycline, minocycline) and glycopeptides (vancomycin, teicoplanin) (Gilbert et al., 2011). In the case of community acquired MRSA (CA-MRSA) infections, due to the resistance mechanism, $\beta$-lactam antibiotics cannot be used, but the susceptibility of these strains to Rother groups of antibiotics seem to be preserved (DeLeo et al., 2010). Nevertheless, the HA-MRSA strains are characterized by resistance to

Table 2. Toxin-mediated diseases

\begin{tabular}{ll}
\hline Toxin & Toxin-mediated diseases \\
\hline TSST-1 & $\begin{array}{l}\text { Menstrual Toxic Shock Syndrome } \\
\text { (MTSS) } \\
\text { Nonmenstrual TSS (NMTSS) }\end{array}$ \\
$\begin{array}{ll}\text { Exfoliative toxins (ET }) \text { A } \\
\text { and B }\end{array}$ & $\begin{array}{l}\text { Staphylococcal Scalded Skin Syn- } \\
\text { drome (SSSS) } \\
\text { Bullous impetigo }\end{array}$ \\
$\begin{array}{l}\text { Staphylococcal enteroto- } \\
\text { xins: SEA, SEB, SEC, SED, } \\
\text { SEE, SEG, SEH and SEl }\end{array}$ & $\begin{array}{l}\text { Staphylococcal Foodborne Diseases } \\
\text { (SFD) }\end{array}$ \\
\hline
\end{tabular}

$\beta$-lactam as well as other above-mentioned antibiotics. If none of the resistance mechanisms to glikopeptides is present (GISA, VRSA), antibiotics of this group are one of the last therapeutic options. Excluding glikopeptides, the HA-MRSA strains can be susceptible to rifampicin, fusidic acid and co-trimoxazole. Rifampicin and fusidic acid are rarely used as in the course of treatment strains easily acquire resistance, and co-trimoxazole is not sufficiently effective in the treatment of acute infections (DeLeo et al., 2010; Gilbert et al., 2011). Currently, three antibiotics recently introduced to routin medicine procedures are available and effective in treatment of HA-MRSA infections: from the oxazolidinone group - linezolid; streptogramin group — quinupristin/ dalfopristin, and from the glycylcycline group - tigecycline (Appelbaum \& Jacobs, 2005; Gilbert et al., 2011). Thus, three therapeutic options are available in the case of multiresistant strain infections. However, they can be insufficient in specific cases i.e. the use of tigecycline in respiratory tract infections or sepsis.

\section{ALTERNATIVE THERAPIES}

\section{A. Natural antibacterial compounds}

New antibacterial substances are sought for and trials with known compounds of different origins are being performed. Research is carried out involving the use of natural substances with antibacterial activity obtained from bacteria (Severina et al., 1998; Giacometti et al., 2000; Kokai-Kun et al., 2003; Nascimento et al., 2006; Oh et al., 2006), plants (Filipowicz et al., 2003; Yin et al., 2004; Yang et al., 2006; Adesokan et al., 2007) and animals (Giacometti et al., 2000; Bexfield et al., 2004; Giacometti et al., 2006).

\section{Bacteria-derived compounds}

Bacteriocins, antimicrobial peptides produced by Staphylococcus, which inhibit the growth of $S$. aureus are termed staphylococcins. They can be produced by both $S$. aureus and $S$. epidermidis. Research on the activity of seven staphylococcins against MRSA strains indicated that two bacteriocins, auricin A53 and Pep5, produced by $S$. epidermidis displayed the widest inhibition spectrum, inhibiting the growth of $87.5 \%$ of examined strains (Nascimento et al., 2006). Gram-positive bacteria from the Lactococcus genus produce polycationic peptide bacteriocins (lantibiotics) activ against both MRSA and MSSA strains (Severina et al., 1998; Giacometti et al., 2000; Oh 
et al., 2006). Some of them are characterized by a wide activity spectrum including Gram-positive bacteria and Gram-negative rods (Oh et al., 2006). Cationic 34-residue peptides produced by Lactococcus lactis displayed activity against MRSA strains with a $\mathrm{MIC}_{90}$ of $16 \mathrm{mg} / \mathrm{L}$ (Giacometti et al., 2000). Lantantibiotics E-50-52 produced by Enterococcus faecium and OR-7 by Lactobacillus salivarius have a MIC for MDR MRSA of $\leq 0.03 \mathrm{mg} / \mathrm{ml}$ and 1 $\mathrm{mg} / \mathrm{L}$, respectively (Svetoch et al., 2008). The commercially available lantantibiotic nisin is produced by Lactococcus lactis (forms A, F, Q, and Z) and Streptococcus uberis (forms U and U2). Field et al. (2008) carried out genetic modification of nisin form $\mathrm{A}$ and obtained derivatives N20P, M21V and K22S with elevated antibacterial activity against $S$. aureus strains, opening a new approach to staphylococcal infection therapy (Field et al., 2008). In another study, nisin at $10 \mathrm{mg} / \mathrm{L}$ displayed activity towards MRSA strains and within three hours caused a 4-fold reduction of viability (Severina et al., 1998). Most of the experiments were performed in vitro but the obtained results allow one to presume that in the future these preparations could find use in the treatment of topic infections, particularly because bacteriocins do not affect the host tissues (Kokai-Kun et al., 2003; Oh et al., 2006; Kokai-Kun et al., 2003; De et al., 2009). In vivo experiments conducted by De et al. (2009) concerned animal model infection. Rats were infected with the rate of colonisation of about $4 \times 10^{5}$ viable cells and were then treated intranasally with nisin F (8192 arbitrary units). That therapy gave a protective effect in comparison with a control grup and, moreover, no histopathological or morphological changes in the animals were reported (De et al., 2009). Next, it has been reported that bacteriocin isolated from Lactococcus spp. HY 44 in the concentration of approximately $50 \mathrm{mg} / \mathrm{ml}\left(\mathrm{LC}_{50}\right)$ for did not show a proliferative effect on human fibroblasts and no allergic reaction in the human patch test (Oh et al., 2006). Mersacidin, a 20 -aminoacid lantantibiotic produced by Bacillus sp. HIL Y-85 54728 in a mouse rhinitis model showed antibacterial activity against MRSA. After intranasal inoculation with $3 \times 10^{2}-10^{4}$ CFU of MRSA, Mersacidin was administered intranasally twice a day over three days, giving complete eradication of MRSA. Moreover, the level of cytokines was elevated in comparison with the pre-treatment state (Kruszewska et al., 2004).

Another bacteria-derived compound examined as antiMRSA agent is lysostaphin. Originally isolated from $S$. simulans it is a glycylglycine endopeptidase capable of specifically cleaving the cross-linking pentaglycine bridges in the cell wall of $S$. aureus. Used in the form of a cream at $0.5 \%$ concentration to eradicate carriers in cotton rats, it was found more effective in comparison with $2 \%$ mupirocin or 5\% nisin (Kokai-Kun et al., 2003). Good therapeutic effects were obtained in experimental rabbit keratitis using $0.3 \%$ lysostaphin in eye drops and in treatment of the endophtalamitis, where $0.1 \%$ concentration was used (Dajcs et al., 2002).

\section{Plant-derived compounds}

Four stilbenoids isolated from Stemona japonica were evaluated as an antimicrobial agents. Two of them displayed high activity towards $S$. aureus (MIC 50 and 25 $\mathrm{mg} / \mathrm{L})$ comparable to that of known antibacterial compounds such as bakuchiol and magnolol (MIC $25 \mu \mathrm{g} /$ $\mathrm{ml}$ ). Filipowicz et al. (2003) examined the activity of three components of juniper berry oil A, B and C. The highest activity against MRSA strains (MIC $1.2 \mu \mathrm{g} / \mathrm{ml}$ ) in comparison to a control strain ATCC 25923 was determined for fraction A comprising the highest concentra- tion of (-) $\alpha$-pinene, $p$-cymene and $\beta$-pinene. Among three new prenylflavonoid corylifols $\mathrm{A}-\mathrm{C}(1-3)$ and 13 prenylflavone derivatives isolated from Psoralea corylifolia seeds, nine presented activity against S. aureus ATCC 25923, with the MIC in the range of $0.018-0.043 \mathrm{mM}$, comparable to that of bakuchiol and magnolol, MIC $0.037 \mathrm{mM}$ (Yin et al., 2004). The activity of aqueous extract of Enantia chlorantha stem bark was examined against various microbes. The highest activity was observed against S. aureus (MIC $25 \mathrm{mg} / \mathrm{L}$ ). Because alkaloids predominated among the solutes $(46.26 \%)$, the authors presumed that they were responsible for the antibacterial activity (Adesokan et al., 2007).

Flavonoids are heterocyclic compouds present in pigment plants in leaves, flowers and fruit. They are divided into 14 classes on the basis of the general structure (Cushnie \& Lamb, 2011; Maia et al., 2011; Oh et al., 2011). They have a broad spectrum of biological activity such as antioxidant, anticancer, immunomodulatory, antiviral, antifungal and antimicrobial (Kilani-Jaziri et al., 2011; Fraga et al., 2010; Ozcelik et al., 2011). Bactericidal activity of flavonoids has been reported against several bacterial species, including $S$. aureus (Verdrengh et al., 2004; Hong et al., 2006; Kilani-Jaziri et al., 2011; Ozcelik et al., 2011), but the mechanism of that activity is still poorly understood (Cushnie \& Lamb, 2011). Kilani-Jaziri et al. (2011) studied Total Oligomer Flavonoids (TOF) extract obtained from Cyperus rotundus and found its MIC for $S$. aureus was $0.5 \mathrm{mg} / \mathrm{ml}$ and $\mathrm{MBC} 1 \mathrm{mg} / \mathrm{ml}$. As a control, ampicillin was used (MIC $0.0015 \mathrm{mg} / \mathrm{ml}$ and MBC $0.225 \mathrm{mg} / \mathrm{ml}$ ) (Kilani-Jaziri et al., 2011). In our opinion, it is extremely difficult to evaluate the real bactericidal activity of a novel substance on the basis of such investigations on a highly sensitive and non- $\beta$-lactamase producing strains as is indicated by its low ampicillin MIC. Hong et al. (2006) studied the inhibitory activity of genistein, a radioprotective soy isoflavone, against opportunistic $S$. aureus that could cause sepsis in patients after radiotherapy. $S$. aures culture $\left(1 \times 10^{3} \mathrm{CFU} / \mathrm{ml}\right)$ was treated with $100 \mu \mathrm{M}$ genistein and after $8 \mathrm{~h}$ of incubation a significant reduction in viable counts was reported $(p<0.05)$. Moreover, genistein had no bactericidal activity against probiotic Lactobacillus reuteri species (Hong et al., 2006). These promising results suggest that genistein with probiotic bacteria could enhance antibiotic therapy in the case of infections in such high risk patients. Verdrengh et al. (2004) revealed that the bactericidal activity of genistein against $S$. aureus is due to its inhibitory action towards topoisomerase IV affecting DNA metabolism. Wang et al. (2010) proved that the antibacterial activity of soybean isoflavone (SI) against $S$. aureus strains results from inhibition of topoisomerases I and II. The activity of the topoisomerases was inhibited by SI at 6.4 $\mathrm{mg} / \mathrm{ml}$. The antimicrobal activity of flavonoids could be due to direct inhibition of bacterial growth as well as to the inhibition of virulence mechanisms (Oh et al., 2011; Budzynska et al., 2011). Oh et al. (2011) investigated 14 flavonoids extracted from Sophora flavescens roots and their ability to inhibit bacterial growth and the activity of bacterial sortase A. Sortase A (SrtA) is a key enzyme involved in the pathogenicity of $S$. aureus. The chemical pHMBC known for its inhibitory property toward SrtA $\left(\mathrm{IC}_{50}=130 \mu \mathrm{M}\right)$ served as a positive control. The highest activity was asigned to kurarinol $\left(\mathrm{IC}_{50}=107 \pm 6.6 \mu \mathrm{M}\right)$, but despite that all of the flavonoids studied revealed weak activity against $S$. aureus growth.

A serious problem especially of chronic infections is formation by microorganisms of biofilm, which is difficult to eradicate with standard antibiotic therapy. 
Thus, researchers are still looking for an alternative options to eliminate the biofilm-forming microorganisms. Budzyńska et al. (2011) studied 22 synthetic flavonoids of which three 3 -arylideneflavones, $2 b, 2 c$, and $2 \mathrm{i}$, revealed efficient antimicrobial activity against $S$. aureus. Interestingly, 3-arylideneflavone $2 \mathrm{c}$ inhibited the initial adhesion of bacteria to abiotic surfaces which resulted in blocking the biofilm formation. Moreover, those authors proved that due to the lipophilic nature the 3-arylideneflavones influence the cel-membrane integrity causing the bacterial growth inhibition. Another mechanism of antimicrobial activity of flavonoids is modulation of antibiotic resistance (Cushnie \& Lamb, 2011; Maia et al., 2011). Maia et al. (2011) revealed that six flavones isolated from Praaxelis clematidea. King and Robinson inhibited staphylococcal NorA efflux pump decreasing the norfloxacin MIC 16-fold in a reference strain of S. aureus SA-1199B. However, inhibition of bacterial growth was not reported. Some flavonoids reduce the oxacillin MIC towards MRSA strains, thereby enhancing their susceptibility to oxacillin and other $\beta$-lactam antibiotics. Epicatechin gallate reduces the MIC value 256-512-fold and the flavone baicalein up to 1024-fold (Cushnie \& Lamb, 2011).

\section{Animal-derivied compunds}

Renalexin, a 20-residue peptide isolated from skin of the bullfrog Rana catesbeiana displayed activity against clinical MRSA strains $\left(\mathrm{MIC}_{90} 16 \mu \mathrm{g} / \mathrm{ml}\right.$ ) (Giacometti et al., 2000). A native thermostabile antibacterial factor isolated from third-instar larvae of Lucilia sericata, composed of two fractions $<500 \mathrm{Da}$ and $0.5-3 \mathrm{kDa}$, demonstrated activity against MRSA and MSSA strains as well as Gram-negative rods (Bexfield et al., 2004). Distinctin, a protein isolated from Pollymedusa distincta, displayed a synergistic effect with glycopeptides towards biofilms in in vitro experiments and in an animal model of $S$. aureusinfected central venous catether (CVC). The bacterial load in the biofilm decreased to $10 \mathrm{CFU} / \mathrm{ml}$ (Giacometti et al., 2006).

The natural amphiphilic steroids squalamine and MSI1436 from the dogfish shark Squalus acanthias exihibited the best antimicrobial activity against $S$. aureus ATCC $29231(1-2 \mu \mathrm{g} / \mathrm{ml})$ comparing to other microorganisms, as Pseudomonas aeruginosa, Proteus vulgaris and Candida albicans (MIC $=4-8 \mu \mathrm{g} / \mathrm{ml}$ ) (Brunel et al., 2005). Since these natural amino sterols are difficult and expensive to obtain, new derivatives have been synthesized showing antimicrobial activity against $S$. aureus with a MIC from 1.56 to $6.25 \mu \mathrm{g} / \mathrm{ml}$ comparing to the MIC for squalamine $<3.125 \mu \mathrm{g} / \mathrm{ml}$ (Salmi et al., 2008a; 2008b). Against MRSA the MIC of those compound ranged between 1.25 and $5 \mu \mathrm{g} / \mathrm{ml}$ as compared to $2.5 \mu \mathrm{g} / \mathrm{ml}$ for squalamine (Salmi et al., 2008b).

Chitosan (poly-D-glucosamine) is a natural polymer obtained from chitin, which occurs in exoskeletons of shellfish and insects. Chemical modification by acetylation results in increased water solubility (Chi et al., 2006). Due to its polycationic character, chitosan derivatives display bactericidal activity against different microorganisms including $S$. aureus strains. At $0.63 \mathrm{~g} / \mathrm{L}$, a chitosan derivative inactivated $99.8 \%$ of studied $S$. aureus strains in vitro (Chi et al., 2007). According to Runarsson et al. (2007), the MICs for methylated derivatives of chitosan towards $S$. aureus strains were lower at $\mathrm{pH} 5.5$ than at $\mathrm{pH} 7.2$ and ranged from 16 to $512 \mu \mathrm{g} / \mathrm{ml}$. In vivo experiments using a mouse model of $S$. aureus-infected wounds confirmed the effectiveness of chitosan acetate bandage improving wound healing (Burkatovskaya et al., 2008).
Propolis is a waxy resinous hive product collected by Apis mellifera bees from tree buds and green plants mixed with secreted bee enzymes. It is used to seal up holes and cracks in the hive. The chemical content of propolis depends on geographical region and plants that grow in the apiary surranding. The main components responsible for its biological activity (antimicrobial, antifungal, antiviral, anti-tumor and immunomodulatory) are polyphenols and flavonoids (Sforcin \& Bankova, 2011; Chaillou \& Nazareno, 2009). Promising results for MRSA eradication were displayed by ethanolic extract of propolis acting synergistically with mupirocin. In a rabbit model animals treated with combination of mupirocin and propolis displayed significantly lower bacterial cell counts than animals receiving either treatment alone $(p=0.0001)$. Moreover, the significant reduction of polymorphonuclear leukocytes count on nasal mucosal membranes was reported $(p<0.05)$ (Onlen et al., 2007).

The majority of natural coumpouds and their deratives display properties that make them promising candidates for topical rather than systemic drugs. The lack of in vivo toxicity bodes well for their usefulness in clinical practice. Nonetheless, further studies are required.

\section{B. Old medications - new uses}

Numerous medicinal compounds used for other purposes are currently being studied for possible antibacterial activity. The aim of these studies is to evaluate their bactericidal activity as well as the possible synergistic action with antibiotics and other antibacterial chemotherapeutics through inhibition of bacterial drug resistance mechanisms. Polyoxotungstates (POT), which sensitizes MRSA strains to beta-lactam antibiotics through the reduction of PBP2a expression, exemplifies such mechanisms. The mechanism responsible for this phenomenon is probably the stress response of MRSA to POT. Sensitization to beta-lactams was also seen with other substances such as fosfomycin, Triton X-100, tannin and some flavonoids (Tajima, 2005).

The antipsychotic drug thioridazine inhibits efflux pump efficiency. The addition of thioridazine to norfloxacin for MRSA lead from 2 to 8-fold reduction of MIC for norfloxacin and oxacillin (Kristiansen et al., 2006). Thioridazine itself displays bactericidal activity against $S$. aureus. However, the concentration of thioridazine in blood serum that is requierd to achieve such bactericidal effect is higher than can be achieved clinically. Thus this compound is more likely to be used synergistically with antibiotics to treat infections with strains with active effux pumps (Thanacoody, 2007).

Sandrini et al. (2007) examined the antibacterial activity of two nucleoside analogue drugs, antiviral AZT (azidothymine) and anticancer Gemcitabine (2',2'-difluoro-2'deoxycytidine, $\mathrm{dFdc}$ ). These analogues are specifically activated by endogenous bacterial deoxyribonucleoside kinases, which results in death of the bacteria. Among the examined AZT analogues, 5-fluoro-2'-deoxyuridine (FdUrd) displayed the highest antibacterial activity, with the MIC for S. aureus ATCC 29213 and CCM 885 of $0.00316 \mu \mathrm{M}$ and $0.01 \mu \mathrm{M}$, respectively. The MIC for gemcitabine was $0.01 \mu \mathrm{M}$ and $1.0 \mu \mathrm{M}$, respectively.

\section{Cationic Antimicrobial Peptides}

Cationic antimicrobial peptides (CAMPs) such as defensins, cathelicidin and thrombocidins are positively charged (+2 to +7$)$ amphipathic molecules with antibacterial properties (Peschel \& Collins, 2001; Zanetti et al., 2002; Hiemstra et al., 2004). Produced by the innate 
immune system they protect the skin and epithelia from the bacteria invasion (Stryjewski et al., 2007). They play a key role in the innate immune response and help in the functioning of neutrophils and platelets, showing a dual mode of action - directly owing to their antibacterial activity and indirectly, by activation of components of the immune system (Zanetti et al., 2002; Pei, 2004). Their mechanism of action is based on their amphipathic hydrophobic and hydrophilic nature which is important for the initial interactions with the bacterial membrane that lead to the disruption of ion homeostasis (Peschel \& Collins, 2001; Peschel, 2002; Pei, 2004). Research is carried out regarding the use in therapy of natural peptides and their synthetic analogues (Benincasa et al., 2003; Giacometti et al., 2004; Cirioni et al., 2006a; Ghiselli et al., 2007) and other compounds with similar characteristics and modes of action (Jin et al., 2005; Chin et al., 2007).

Protegrins were originally isolated from porcine leukocytes. They are 16-18-residue cysteine-rich peptides (Zanetti et al., 2002). IB-367 is a synthetic protegrin used in co-treatment of $S$. aureus infections with linezolid in an experimental model of CVC-associated infections (Ghiselli et al., 2007). When a catheter was treated with IB-367 at $10 \mu \mathrm{g} / \mathrm{ml}$ with linezolid $(32 \mu \mathrm{g} /$ $\mathrm{ml}$ ) a decrease in the number of cells in blood culture from $7.8 \times 10^{4} \mathrm{CFU} / \mathrm{ml}$ to $10^{1} \mathrm{CFU} / \mathrm{ml}$ was observed and in the catheters/venous tissue culture the decrease was from $7.5 \times 10^{5} \mathrm{CFU} / g$ to $4.8 \times 10^{2} \mathrm{CFU} / \mathrm{g}$. In in vitro experiments the MIC of linezolid for $S$. aureus in the presence of IB-367 decreased four times in comparison with a culture without IB-367 and it was at the same level as for planktonic cells (Ghiselli et al., 2007). Similar research was conducted by Cirioni et al., (2006a) who pre-treated central venous catheters with the 27-residue cathelicidin BMAP-28. In in vivo studies, when CVC were treated with BMAP-28 and subsequently with vancomycin or linezolid a reduction in the biofilm bacterial load from $10^{3}$ to $10^{1} \mathrm{CFU} / \mathrm{ml}$ was obtained and bacteremia became undetectable. In the presence of BMAP-28, the in vitro MIC for linezolid decreased 4-fold. In experimental acute peritonitis in mice caused by MRSA, BMAP-28 treatment reduced the mortality to control values (Benincasa et al., 2003). BMAP-28 not only acted synergistically with antibiotics reducing their MIC but also protected mice from the development of sepsis. When live $S$. aureus cells were administered to mice and a combined antibiotic and BMAP-28 therapy was applied, the factors induced a similar reduction of mortality in infected mice. When dead cells were administered only, BMAP reduced mortality due to decreasing the level of tumor necrosis factor- $\alpha$ and interleukin- 6 in the serum, thus indicating its ability to inhibit the development of septic shock (Giacometti et al., 2004).

Caregnins CSA- 8 and CSA-13 are synthetic cationic steroid molecules which resemble in their mode of action endogenous antimicrobial peptides. In tests towards 50 clinical glycopeptide heterointermediate S. aureus (hGISA) and glycopeptide-intermediate S. aureus (GISA) strains and four VRSA ones CSA-13 showed high activity with a 4-fold lower MIC $(1 \mu \mathrm{g} / \mathrm{ml})$ for VRSA in comparison with CSA-8. The MIC $_{90}$ for hGISA and GISA was $1 \mu \mathrm{g} / \mathrm{ml}$ and for CSA- $8,8 \mu \mathrm{g} / \mathrm{ml}$ (Chin et al., 2007). Urokinase-type plasminogen activator (uPA) is a serine protease produced in an inactive form mainly by the kidneys. The activated form has fibrinolytic function and modulates the innate immune response. In in vitro and in vivo experiments, uPA displayed antibacterial activity towards $S$. aureus, therefore it acted as an endogenous antibiotic and the effect was dose-dependent (Jin et al., 2005).

Unlike the previously described compounds, endogenous peptides seem to have potential in parenteral therapy. However, similarly to most compounds with antibacterial activity there is a risk of a lack of efficacy towards strains inducing infections. The negative net charge of both staphylococcal teichoic acid and phospholipids plays a key role in the susceptibility to CAMPs (Peschel \& Collins, 2001; Peschel, 2002; Hiemstra et al., 2004). Due to the fact that most endogenous peptides have a positive charge, ionic forces lead to the accumulation of the peptides in the cell wall, interactions with the surface of the cell membrane, integration with the lipid layer and pore formation (Peschel \& Collins, 2001; Peschel, 2002; Hiemstra et al., 2004). It is recognised that acquiring resistance to cationic peptides is based on the modulation of the electrical charge of the wall and cell membrane, which leads to the reduction in the interactions with the peptide antibiotics. This can take place by modification of the teichoic acid in the cell wall by incorporation of D-alanine or modification of phosphatidylglycerol by Llysine as well as by efflux pump ( $\operatorname{gac} A$ ) activation (Peschel, 2002).

Dendrimers, low molecular mass peptides are synthetic analogs of natural, linear antimicrobial peptides, but have a branched structure. Their mechanism of action is similar to that of cationic peptides and is based on interactions with the bacterial membrane. Janiszewska and Urbanczyk-Lipkowska (2006) studied various dendrimers and found that the MICs for $S$. aureus ranged from $64 \mu \mathrm{M}$ for dendrimer $169,-69 \mu \mathrm{M}$ for dendrimer P13, $-75 \mu \mathrm{M}$ for dendrimer 155 and to $-144 \mu \mathrm{M}$ for P2. When tested against $S$. aureus, E. coli and C. albicans, dendrimer P13 was the most effective overall with a MIC of 69, 32 and $69 \mu \mathrm{M}$, respectively. However, against $S$. aureus specifically, dendrimer 169 was the most effective.

Current knowledge indicates that peptide antibiotics should be viewed as highly potent agents for treatment of multidrug resistant maicroorganisms-related infections. Moreover, it is suggested that peptide antibiotics, unlike the bacteria-originated antimicrobial agents, could display a lower potential for supression of the physiological flora. Synthetic analogs of endogenously produced peptides can be chemically modified to modulate their effeciveness and eliminate produced side-effects. Moreover, the antimicrobial activity as well as ability to modulate host imunne response make the peptide antibiotics highly promising. Such chemical modifications lead to inhibition of septic shock syndrome due to reducing the level of septic shock mediators. Such effect could not be obtained with the use of other groups of antibiotics. Peptides could activate the host cellular immune respons, which is extremly important in the case of multifactorial pathogenesis of staphylococcal infections. Obviously, acquisition of resistance to peptide antibiotics can also take place, thus susceptibility testing seems to be required before the treatment.

\section{Prevention of biofilm formation}

A protection strategy against biofilm formation is based on the prevention of staphylococci adhesion to the host cell or to the surface of synthetic materials used in various types of catheters and implants (Balaban et al., 2003; Dell'Acqua et al., 2004; Cirioni et al., 2006a; Balaban et al., 2007). Introducing new less hydrophobic biomaterials (Campoccia et al., 2006) as well as covering their surface with antibiotics and antiseptics can pre- 
vent the adhesion of biofilm-forming bacteria (Richards et al., 2006; Ghiselli et al., 2007; Bahna et al., 2007). As far as biofilm production is concerned, disruption of quorum sensing as well as the expression of virulence factors with RNAIII-Inhibiting Peptide (RIP) reduced the growth of bacteria and allowed access of antibiotics (Balaban et al., 2001; 2003; Korem et al., 2003; Cirioni et al., 2006b). RIP is a hexapeptide, which in S. aureus inhibits the synthesis of toxins by interference with the RNAIII Activating Protein (RAP) (Korem et al., 2003). The RAP is a protein which activates the production of many toxins through phosphorylation of the RAP target - TRAP. If its expression or phosphorylation is disrupted by the RIP, the expression of the virulence regulator, agr gene, is inhibited and „quorum sensing” is blocked (Korem et al., 2003; Cirioni et al., 2006b). Balaban et al., (2003) reported that the RIP inhibited the adhesion to HaCat (human skin keratinocytes) and Hep-2 (human epithelial cells) and also reduced the adhesion to dialysis catheters, both those made of polyurethane and of silicone. Moreover, RIP was found more effective against strains with a high adhesion affinity (Balaban et al., 2003). In vitro studies revealed that the treatment of $S$. aureus cells in a biofilm with RIP and subsequent addition of an antibiotic produced a significant decrease in the MICs and MBCs to values comparable to those obtained for planktonic cells. It was shown that the RIP alone displayed no bacteriostatic or bactericidal activity. These results were confirmed in an in vivo model of rats with staphylococci CVC (central venous catheter) infection. The application of RIP and antibiotics greatly reduced the bacterial load in the biofilm by $6 \log _{10}$ (Cirioni et al., 2006b). In research carried out by Balaban et al., (2000), bacteria pre-incubated with the RIP were used to induce infection in vivo. Strains treated with the RIP caused less frequent infections than untreated strains by $40 \%$ and $58 \%$ for keratitis and osteomyelitis in rabbits, respectively; by $60 \%$ for septic arthritis in mice and by $70-100 \%$ for mastitis in cows.

Simonetti et al., (2008) revealed that in the case of MRSA-infected wounds dressing soaked with RIP significantly enhanced wound healing in mice. Additionally, also mice treated intraperitonally with teicoplanin showed better healing. No side effects were observed.

The therapeutic strategy based on counteracting the biofilm formation seems to be more promising and safe than biofilm eradictation in the course of treatment. The simultaneous administartion of antibiotics and RIP inhibiting quorum sensing revealed a synergistic action im biofilm reduction. Moreover, in vivo studies indicate that such an approach could be used in the treatment of local as well as generalized infections treatment.

\section{E. Bacteriophages}

Untill now, bacteriophages have been used in therapy mainly in Eastern European countries and the former Soviet Union. There are no formal regulations and standards for biocteriophage therapy despite their use in a large number of patients (Keilman, 1979; Slopek et al., 1987; Sulakvelidze et al., 2001; Parfitt, 2005). As described by Verbeken et al. (2007), the studied therapies must be in accordance with paragraph 32 of the Declaration of Helsinki and under supervision of an Ethics Committee. In June 2007, a limited clinical trial was approved by an Ethics Committee to be performed in the Burn Wound Center in Belgium (Verbeken et al., 2007). In 2005 in Poland, the Istitute of Immunology and Experimental Therapy of the Polish Academy of Sciences began experimental treatment of outpatients. Three formal conditions had to be met, namely: approval by an institutional review board, a written informed consent of patients, and insurance (Gorski et al., 2009). There is still a lack of well documented research including controls, therefore robust conclusions as to the usefulness and dangers of bacteriophage therapy cannot be made (Sulakvelidze et al., 2001). Nevertheless, phage therapy seems to be worth further investigation due to its underlying concept. Phage selectively kills only the target bacteria and in the case of $S$. aureus infections both MSSA and MRSA strains are susceptible (Matsuzaki et al., 2003; Capparelli et al., 2007). While the antimicrobial activity of an antibiotic includes both pathogenic bacteria as well as the physiological flora, a key problem of phage therapy is selection of a phage specific to different strains of a certain species. Sulakvelidze et al., (2001) mention other advantages of phage therapy. Phages replicate in the infection site and do not cause side-effects, moreover, bacteria that are resistant to some phages can be sensitive towards others.

A drawback of this sort of therapy can be a narrow spectrum of sensitive strains, which can require the use of a mixture of phages. It is also essential to select lysogenic phages due to the risk of transferring genes encoding toxins and resistance to antibiotics (Sulakvelidze et al., 2001). Parfitt (2005) describes the clinical use of phage therapy in Georgia, where this therapy helped to reach a clinical state enabling plastic surgery in three patients with purulent staphylococci-infected burns caused by a radioactive agent. This therapy is based on using a synthetic skin soaked in phages, from which they are slowly released to the environment of the wound as a consequence of slow biodegradation of the artificial skin (Parfitt, 2005). Keilman (1979) presented results regarding the local treatment of purulent bone inflammation. Polyvalent phages were used in combination with locally applied antiseptics parallel to surgical intervention and antibiotic treatment. As a result a reduction in purulent complications from $23.2 \%$ to $4.8 \%$ was observed. New research regarding this subject has also been presented in several publications (Matsuzaki et al., 2003; Wills et al., 2005; Capparelli et al., 2007). In an experimental treatment of abscesses in rabbits with the LS2a phages, a significant eradication of infection was obtained (Wills et al., 2005) and the use of the MR11 phage to treat MRSA peritonitis in mice prevented death up to seven days (after this time they were killed), whereas in the non-treated control group the mortality after $24 \mathrm{~h}$ was above 90\% (Matsuzaki et al., 2003). The MR11 phage was selected due to its widest spectrum towards various $S$. aureus strains and also because it does not transfer toxin and resistance genes (Matsuzaki et al., 2003). A suspension of $\mathrm{M}^{\mathrm{Sau}}$ phages brought about total infection eradication in mice and only $3 \%(1 / 30)$ died. This phage also has a wide spectrum of activity towards many $S$. aureus strains including MRSA. In a control (non-treated) group $100 \%(30 / 30)$ mice died $(p<0.0001)$ (Capparelli et al., 2007). In a model of catheter-related infection, $\lambda 80$ phage reduced the optical density of a $24 \mathrm{~h}$ biofilm by 79.4\% (Del Pozo et al., 2007). Leszczyński et al., (2006) described the use of phages in eradication of MRSA carriage in a health worker. A nurse, who suffered a urinary tract infection caused by MRSA, after a successful treatment became carrier in the digestive tract. She refused eradication with antibiotics but agreed to bacteriophage treatment. Phage lysate was administered orally and decolonization was completed successfully. 
Phages have also been used as vectors to increase the efficacy of therapy (Embleton et al., 2005; Yacoby et al., 2007). Yacoby et al., (2007) reported the use of phages in the transfer of antibiotic molecules to the bacterial cell. During the first stage of the research, trials involved the direct transport of chloramphenicol with the help of filamentous bacteriophages to $S$. aureus cells. However, the effect of bacterial growth inhibition was only partial due to the transfer of a small amount of the drug caused by its hydrophobicity. Bacteriophage 75 complex was used to transfer a photosensitizer and light-activated antimicrobial agents to $S$. aureus cells. On exposure to light, this complex killed different MSSA, MRSA and VISA cells. The use of a control consisting of phage only showed that the killing effect was not a consequence of bacteria lysis by the phage (Embleton et al., 2005).

The current knowledge suggests that bacteriophagerelated thaerapy should mainly concern the treatment of local infections as well as survaillance eradication especially in the case of drug-resistant pathogenes. Nevertheless, in vivo studies indicate that in the nearest future phage-related therapy will not be applied to severe multiorgan infections or generalized infections. Such cases would prompt the host immune system to eliminate bacteriophages as a foreign agents before their could act against the pathogens. Moreover, it is hardly possible for a bacteriophage culture to be standarized as viruses mutate easily. Next, this alternative approach involves three live components - patient, bacteria and virus - thus the final result could be difficult to predict. Undoubtedly, the obvious benefits of phage-related therapy in comparison with antibiotic therapy include low cost and relatively short time of preparation of new agents.

\section{F. Photodynamic therapy}

Photodynamic therapy (PDT) is based on the use of chemicals termed photosensitizers. Photosensitizers accumulate in specifically selected tissues or cells and their activation is a result of the activity light of an adequate wavelength. This leads to the generation of singlet oxygen and free radicals responsible for the cytotoxic effect towards specific cells (Hamblin et al., 2002; Romanova et al., 2003; Mohr \& Redecker-Klein, 2003; Jori and Brown 2004). Some mechanisms responsible for the cytotoxic effect have been examined and characterized. Depending on the photosensitizer used, the mechanism can be associated with cell wall disruption, inactivation of enzymes or indirect damage to the genetic material of the bacteria (genomic and plasmid DNA) (Romanova et al., 2003; Sharma et al., 2008).

$\mathrm{Up}$ to now mainly preliminary investigations have been performed, such as analyzing the survival rate of bacteria in vitro, depending on the type and dose of the photosensitizer, wavelength and illumination duration (Maisch et al., 2005; Grinholc et al., 2007a; 2008a; 2008b; Sharma et al., 2008; Peloi et al., 2008).

From a clinical point of view, an important issue is easy killing of the multi-resistant MRSA strains in response to photodynamic therapy as development of resistance to this therapy seems to be unlikely, in contrast to the quick gaining of resistance towards different antibiotics and other antibacterial agents (Hamblin \& Hasan, 2004; Grinholc et al., 2007a).

Grinholc et al. (2008b) reported that the response to photodynamic inactivation with protoporphyrin diarginate $\left(\mathrm{PPArg}_{2}\right)$ was different among various clinical MSSA and MRSA strains and ranged from 0 to $3 \log _{10}$ unit reduction in viable counts. Assuming a reduction of 1-2 $\log _{10}$ units as criteria of sensitivity and reduction of $2-3$ $\log _{10}$ units as high sensitivity, $62.5 \%$ of MSSA and $40 \%$ of MRSA were sensitive and multidrug-resistance correlated with resistance to photodynamic therapy $(p<0.05)$. Comparing in vitro biofilm-forming strains with non-biofilm-forming strains, a higher killing efficacy was observed in the latter. Among the highly sensitive strains $\left(>2 \log _{10}\right) 75 \%$ did not produce a biofilm (Grinholc et al., 2008b). It is worth to emphasize that susceptibility of different strains to photodynamic inactivation was not studied earlier and investigations along these lines should be continued. Determination of molecular markers predicting strain response to photo-inactivation would lead to more effective treatment (Grinholc et al., 2008b). Sharma et al. (2008) reported high in vitro efficacy of toluidine blue (TBO) used with laser light in the reduction of MRSA biofilm, where the reduction effect was dependent upon the light dose (Sharma et al., 2008). Recent discoveries showed that sensitivity of $S$. aureus strains to broadband visible light is also strain-dependent indicating that the level of hydroxyl and superoxide radical production determines the strains' response to photoinactivation (Lipovsky et al., 2009).

So far, few papers on in vivo studies have been published (Soukos et al., 1998; Komerik et al., 2003; Wilson 2004). On the basis of the results obtained by Bisland et al. (2006) on animal models, it can be assumed that photodynamic therapy is potentially one of the best therapeutic options for treating osteomyelitis of $S$. aureus etiology, especially that these infections are associated with a biofilm production. An obvious advantage of photodynamic therapy stems from its mechanism involving singlet oxygen generation that makes it impossible to induce effective resistance mechanisms (Wilson, 2004). Importantly, unlike antibiotic treatment photodynamic therapy does not influence the physiological bacterial flora (Romanov et al., 2001; Wilson, 2004) owing the possibility of specific introduction of the photosensitizer to selected bacterial cells and also to the restricted illumination area (Hamblin \& Hasan, 2004). An additional advantage of this method is its low cytotoxic effect towards host cells along with the high efficacy towards pathogens (Soncin et al., 2002; Grinholc et al., 2008a) and also a lack of any direct or delayed damage to the genetic material (Zeina et al., 2002; 2003).

\section{G. Staphylococcal vaccines}

Literature regarding staphylococcal vaccines is very comprehensive, however, there is still a problem with the introduction of a efficient vaccine in the prevention of infections caused by $S$. aureus. This can be associated with the fact that a human organism throughout its life is in contact with this bacterium as many people are constant or transient carriers of $S$. aureus on the mucus of the nasal or oral cavity. The selection of patients for this preventative therapy should be based on recognizing the risk factors and should be preceded by research to allow individualized approach (Fattom et al., 2004; Schaffer \& Lee, 2008). Earlier the whole bacterial cell was used as an antigen, but recent research is aiming at obtaining antibodies against specific virulence factors such as adhesins, toxins or invasins (Otto, 2008). Despite the multicomponent regulation of pathogenesis, interference with any component can reduce virulence and symptoms of disease (Balaban et al., 2000).

Nonetheless, despite the substantial progress in recent years, no vaccine has yet been approved and in fact only one, StaphVAX ${ }^{\mathrm{R}}$, successfully underwent clinical trials 
(Deresinski, 2006; Schaffer \& Lee, 2008). StaphVAX ${ }^{\mathrm{R}}$ is a bivalent vaccine composed of $S$. aureus capsular polysaccharide (CPS) types 5 and 8 conjugated with a nontoxic Pseudomonas aeruginosa exotoxin (Fattom et al., 2004). These antigens were chosen because these capsular types are the most often described for strains isolated from infected patients (Otto, 2008; Sadowska et al., 2001; Deresinski, 2006). However, clinical phase II and III studies indicate that the vaccine offers only a partial protection from bacteremia lasting for a few weeks in $60 \%$ of immunized patients (Shinefield, 2006). Due to the planned expansion of the activity spectrum of the vaccine to S. aureus 336, S. epidermidis PS-1, S. epidermidis GP-1 and PVL antigens, Nabi Biopharmaceuticals suspended the research (Deresinski, 2006). Currently, Merck conducts clinical phase II trials concerning vaccine V710 (previously designated $0657 \mathrm{nl}$ ), where the antigen used is a cell-wall-anchored IsdB protein (Schaffer \& Lee, 2008). Iron surface determinant $\mathrm{B}$ (Is $\mathrm{dB})$ is an iron-sequestering protein conserved in various clinical MSSA and MRSA strains. It is characterised by an iron binding ability that enables bacteria to obtain it from the environment. Its expression occurs when iron level is low in the growth environment of the bacteria (Kuklin et al., 2006). Clinical trails are conducted with patients undergoing hemodialisis and cardiosurgery (Schaffer \& Lee, 2008).

The IsdB protein perfectly exemplify the direction of effort to create a vaccine against $S$. aureus vaccine. IsdB is present in all clinical $S$. aureus strains, thus the antimicrobial effectiveness of an IsdB-based vaccine is suggested to be much higher than in the case of vaccines targeting capsular polysaccharide (CPS) types 5 and 8. Moreover, IdsB as a protein should trigger significantly higher immunological response than capsular polysaccharides. Such vaccines would not be effective against bacteria bearing other serotypes of CPS.

Clinical phase II trials are also underway for some drugs used for passive immunization comprising immunoglobulins against ClfA (Tefibazumab [Arexis] company Inhibitex), ABC transporter GrfA (Aurograb - NeuTec), lipoteichoic acid (Pagibamaximab [BSYXA110] — Biosynexus) and CP5 and CP8 (AlfaStaph Nabi). The lack of a clinically approved vaccine against $S$. aureus justifies the ongoing search for novel antigenic determinants in the bacterial cell as potential vaccine targets.

The MSCRAMM adhesion proteins are located on the surface of the cell. Antibodies directed against them could block the binding of the microorganism to a host tissue preventing colonization and infection initiation (Otto, 2008). Research is carried out in two directions, namely immunization by application of the surface proteins and in consequence induction of an immune response (Rennermalm et al., 2001; Josefsson et al., 2001; Shannon et al., 2006; Kuklin et al., 2006; Zhou et al., 2006) as well as by DNA vaccines comprising genes encoding specific surface proteins. DNA vaccines induce the expression of encoded proteins in eukaryotic cells, thereby generating an immune response in the form of specific antibodies. As shown, these proteins can also modify the cell-mediated immune response (Brouillette et al., 2002; Kerro-Dego et al., 2006; Gaudreau et al., 2007; Therrien et al., 2007).

In many in vivo studies interesting results have been obtained. When Extracellular Fibrynogen-Binding Protein $(\mathrm{Efb})$ was used for immunization of mice with foreign-body-associated wound infection, it induced a strong immune response that reduced the severity of the infection. Only $17 \%$ of mice developed a serious infec- tion in comparison to $73 \%$ in the control group (Shannon et al., 2006). Josefsson et al. (2001) reported that in experimental septic arthritis in mice, immunization with recombinant ClfA induced a less severe course of disease, and passive immunization with rat or rabbit antiClfA antibodies protected against severe arthritis and sepsis-induced death. ClfB, a protein binding cytokeratin-10, plays an important role in the colonization of the nasal passage, a known risk factor for $S$. aureus infection. Mice immunized systemically or intranasally with a vaccine containing the $\mathrm{A}$ domain of $\mathrm{ClfB}$ displayed a lower level of colonization than a control group. A vaccine containing a truncated D2-domain of fibronectinbinding protein $(\mathrm{FnBP})$ displayed on a cow-pea mosaic virus carrier induced protection against endocarditis in a rat model (Rennermalm et al., 2001). Application with an adjuvant induced a strong response in mice protecting them from infection and sepsis and in rhesus macaques a five-fold increase in the production of antibodies was observed after a single dose (Kuklin et al., 2006). Both single surface-proteins as well as conjugated proteins can serve as antigens. Due to the potentially wider protection spectrum and stronger immune response research on conjugated vaccines containing two or more antigens is being carried out. A recombinant vaccine containing Cna-FnBP induced a strong humoral response which was the highest around 5 and 6 weeks after immunization. This resulted in a higher survival rate of infected mice in comparison to a group immunized with Cna or FnB individually (Zhou et al., 2006).

\section{Polyvalent vaccines}

In a mouse model of abscess formation, immunization with a vaccine containing four proteins IsdA, IsdB, $\mathrm{SdrD}$, and $\mathrm{SdrE}$ induced complete protection in contrast to only partial one obtained with any single antigen. These four antigens were selected as they induced the highest level of antibodies among fifteen tested. A positive correlation was observed between the level of antibodies and opsonophagocytic properties (StrangerJones et al., 2006). Conjugated vaccines were also examined in the context of DNA-mediated immunization and expression of the products of genes. The immune response in mice was evaluated after DNA vaccination with plasmids encoding an individual antigen or a chimeric protein composed of the surface-located GapB and GapC proteins. The recombinant vaccine induced a stronger humoral response than a vaccine bearing either single gene (Kerro-Dego et al., 2006). For a polyvalent vaccine containing genes encoding the sortase enzyme (ClfA-FnBPA-Srt), the combination of genes induced a better response than any of the genes alone. Moreover, the conjugated vaccine induced a T1 and T2 response giving a protective effect from the complex pathogenesis of $S$. aureus. After 21 days post-infection, 55\% of mice immunized with the multi-gene vaccine survived in comparison to a control group where only $15 \%$ survived (Gaudreau et al., 2007). However, not all of the obtained results regarding vaccines containing surface proteins are clear. Therrien et al. (2007) reported that immunization with a DNA vaccine containing the cna gene did not protect mice from a lethal-induced infection. In fact, the only mice that died in the experiment were the immunized ones.

\section{Vaccines against biofilm}

A surface polysaccharide poly- $N$-acetylglucosamine (PNAG), present in $S$. aureus and S. epidermidis, partici- 
pates in biofilm production (Maira-Litran et al., 2004; Perez et al., 2009). Its production is encoded by a gene from the ica locus, which is present in most clinical $S$. aureus isolates. This compound displays immunogenic properties and therefore could be a good vaccine candidate (McKenney et al., 1999; Maira-Litran et al., 2004; Maira-Litran et al., 2005). In a mouse renal infection model the application of PNAG induced a high level of IgG antibodies (>500 UI/ml). Rabbits immunized with PNAG produced even higher levels of antibodies $(>2500 \mathrm{UI} / \mathrm{ml})$ at a constant level for at least 8 months. Comparing the efficacy of PNAG and its deacylated (dPNAG) form conjugated with diphteria toxoid (DT) carrier protein used to immunize animals, a marked increase in the level of antibodies was obtained with dPNAG as opposed to native PNAG (Maira-Litran et al., 2005). Because the efficacy of antibodies against a carbohydrate vaccine may not include all $S$. aureus strains as not all express this polysaccharide despite the presence of the ica locus (Grinholc et al., 2007b), new candidates for the production of an efficient vaccine in chronic infection therapy and prevention are being sought for. Proteins immunogenic in MRSA-induced chronic osteomyelitis with biofilm formation were examined in a rabbit model of tibial infection. Among the 22 antigens identified, antibodies for some of them such as lipase, autolysin or lipoprotein were produced at an early stage on the $14^{\text {th }}$ day of infection. In the case of other antigens, transketolase or elongation factor, antibodies were produced during the late stages of infection on the $42^{\text {nd }}$ day. The authors suggest that antigens that are recognized earlier are good vaccine candidates and those recognized in late stages can be used in adjuvant therapy (Brady et al., 2006).

PNAG is a weak immunogen, so increasing the effectiveness of vaccination, especially with the use of antigens secreted at different stages of biofilm formation taking advantage of the above considerations is an attractive option. Investigations aimed at identyfication of patients that should be vaccinated and those that should be administered with an adjuvant are a prerequisite. They should be based on detailed bacteriological and serological diagnoses.

\section{Vaccines against extracellular proteins}

Another approach involves the use of vaccines against extracellularly secreted proteins with superantigen (exotoxin) properties such as TSST-1, enterotoxin $\mathrm{B}$ (LeClaire et al., 2002) and enterotoxin C ( $\mathrm{Hu}$ et al., 2006; Chang et al., 2008) or other virulence factors as $\alpha$-hemolysin (Hla) (Bubeck \& Schneewind, 2008) and the Panton-Valentine leukocidin (PVL) (Brown et al., 2009). An intranasal application of conjugated vaccines containing a non-toxic mutant of toxic shock syndrome toxin 1 (TSST-1) and non-toxic heat labile mutant toxin (mLT) of E. coli effectively induced an increase in the level of anti-TSST-1 antibodies in the serum and in the nasal secretion. They protected mice from both colonization of the nasal cavity and also from systemic infection (Narita et al., 2008). Two highly immunogenic fragments of enterotoxin $B(\mathrm{SEB})$ induced the production of specific antibodies in chicken. Passive immunization of the rhesus monkeys with these antibodies protected them from death after intranasal application of lethal dose of SEB (LeClaire et al., 2002). In other experiments intranasal immunization with a non-toxic double SEC mutant and cholera toxin (CT) as an adjuvant protected mice from infection (Hu et al., 2006). Bubeck and Schneewind (2008) with the use of a mutant $\alpha$-hemolysin (Hla H35L) which does not form pores obtained specific antibodies in mice which protected them from $S$. aureus-induced pneumonia. Moreover, the anti-Hla antibodies not only protected naive animals from the development of infection but also human lung epithelial cells from damage following infection (Bubeck \& Schneewind, 2008). In another study mice with pneumonia that additionally developed skin infection challenged with epidemic community acquired MRSA (CA-MRSA) strain USA300 revealed a high anti-PVL response after immunization with PVL (Panton-Valentine Leukocidin). Depending on the way of immunization, the protection against one of the infections could be obtained. Intranasal vaccination protected from the pulmonary infection but not from the intradermal one, while subcutaneous vaccination protected against the intradermal but not the pulmonary infection (Brown et al., 2009).

Vaccines against $S$. aureus-secreted virulence factors (exotoxins and toxin-like enzymes, Table 2) are suggested to be of limited use as it is hard to determine the group of patients to be vaccinated. Hypothetically, it could concern the personnel of health-care-associated centers with inefficient hygienic procedures like orphanages, nursing centers, prisons especially when increased numbers of infected patients are reported, e.g. patients suffering from pneumonia or PVL $+S$. aureus cellulitis, or in case of an epidemy of staphylococcal food-borne diseases (SFD).

\section{Vaccines against other virulence factors}

Other targets essential for $S$. aureus virulence have also been examined. The RNAIII activating protein (RAP), which is important for regulation of virulence, was given to mice and a protective effect against infection was obtained in $72 \%$ of them in comparison with $30 \%$ in a control group $(p<0.0001)$ (Balaban et al., 1998). MRSA infections are difficult to treat due to the resistance mechanism and the limited therapeutic options. A vaccine directed against the PBP2a (penicillin-binding rotein 2a) protein showed potential to improve therapy outcome and long-term prognosis. Senna et al. (2003) cloned an internal region from the transpeptidase domain of PBP2a into a mammalian expression vector which was then used as a DNA vaccine for immunization of mice. After three rounds of immunization a significant increase in the level of specific anti-PBP2a antibodies was obtained and the bacterial load in kidneys was zero (in $80 \%$ of the examined animals $)(p<0.015)$ indicating the efficacy of immunization.

PBP 2a inhibition-based strategy seems to be a promising approach. Indeed, it would not prevent infections, but rather would extend therapeutic options by restoring the sensitivity of bacteria to $\beta$-lactam antibiotics. Following this idea, it would be interesting to evaluate if blocking mecA or the SCCmec (Staphylococcal cassette chromosome mec) element blocking would restore the susceptibility to $\beta$-lactams or other groups of antibiotics.

\section{H. Other factors}

Fibronectin-binding proteins $(\mathrm{FnBP})$ are responsible for adherence of $S$. aureus to and subsequent internalization by phagocytes. Intramuscular application of a recombinant fragment of the fibronectin-binding domain $(\mathrm{rFnBF})$, which potentially inhibits the entrance of $S$. aureus to host cells, counteracted the formation of abscesses in guinea pigs. The protective effect was dosedependent and increased the efficacy of preventive treatment if applied simultaneously with cefazolin. The ef- 
ficacy of this method relies on the competition in the adhesion of exogenic $S$. aureus $\mathrm{rFnBF}$ with $\mathrm{FnBP}$, which causes infection (Menzies et al., 2002).

The use of a global regulation system - accessory gene regulator ( $a g r)$ — to reduce strain virulence, is an example of a new promising therapeutic strategy (Cheung et al., 2004).

It has also been reported that the Autoinducer Protein (AIP) originated from one S. aureus strain may either activate or inhibit the expression of RNAIII, which can block the activity of the agr regulon in other $S$. aureus strains. It can also potentially be a therapeutic option and deserves further investigations. The bacterial quorum-sensing system could be deregulated with the AIP protein, preventing biofilm production. Nevertheless, it ought to be taken into consideration that modulation of the agr regulon can inhibit production of some virulence factors while simultaneously activating the expression of others (Harraghy et al., 2007).

\section{SUMMARY}

The treatment of high risk patients without applying appropriate antibiotic policy in hospitals generates various antibiotic-resistance mechanisms among microorganisms. It limits the use of commonly available antibiotics and antimicrobial drugs. Moreover, the spread of resistant bacterial strains across the world becomes more and more common and threatens enhanced morbidity and mortality. Because of multidrug resistance, especially among HA-MRSA, alternative and effective therapeutic options as well as prophylaxis of microbial infections are badly needed. Some of the compounds and methods still need many further studies, some of them seem to be promising in approaching a clinical use in not too-distant a future.

\section{Authors' contributions}

JK wrote chapters Antibacterial Natural Compounds, Old Medicaments - New Approach, Cationic Antimicrobial Peptides, Bacteriophages, and Staphylococcal Vaccines.

MG wrote chapters Staphylococcal Diseases, Preventing Biofilm Formation, Photodynamic Therapy, and Other Factors.

Both authors read and approved the final manuscript.

\section{Acknowledgements}

We are grateful to Prof. Grzegorz Wegrzyn (University of Gdansk, Gdańsk, Poland) for scientific consultations and Anna Kawiak and Agnieszka Wojtkowiak for linguistic consultations.

\section{Funding}

This work was supported by grants no. N N405 165139 and IP2010 010970 from the Ministry of Science and Higher Education (MNiSzW). The publication is financed from the European Social Fund as a part of the project "Educators for the elite — integrated training program for $\mathrm{PhD}$ students, post-docs and professors as academic teachers at the University of Gdansk" within the framework of Human Capital Operational Programme, Action 4.1.1, Improving the quality of educational offer of tertiary education institutions. This publication reflects the views of the authors only, and the funder cannot be held responsible for any use which may be made of the information contained herein.

\section{REFERENCES}

Abele-Horn M, Schupfner B, Emmerling P, Waldner H, Goring H (2000) Persistent wound infection after herniotomy associated with small-colony variants of Staphylococcus aureus. Infection 28: 53-54.

Adesokan A, Akanji MA, Yakubu MT (2007) Antibacterial potentials of aqueous extracts of Enatia chlorantha stem bark. Afr J Biotech 6: 2502-2505.

Appelbaum PC, Jacobs MR (2005) Recently approved and investigational antibiotics for treatment of severe infections caused by Gram-positive bacteria. Curr Opin Microbiol 8: 510-517.

Bahna P, Dvorak T, Hanna H, Yasko AW, Hachem R, Raad I (2007) Orthopaedic metal devices coated with a novel antiseptic dye for the prevention of bacterial infections. Int J Antimicrob Agents 29: 593-596.

Balaban N, Cirioni O, Giacometti A, Ghiselli R, Braunstein JB, Silvestri C, Mocchegiani F, Saba V, Scalise G (2007) Treatment of Staphylococcus aureus biofilm infection by the quorum-sensing inhibitor RIP. Antimicrob Agents Chemother 51: 2226-2229.

Balaban N, Collins LV, Cullor JS, Hume EB, Medina-Acosta E, Vieira da MO, O’Callaghan R, Rossitto PV, Shirtliff ME, Serafim da SL, Tarkowski A, Torres JV (2000) Prevention of diseases caused by Staphylococcus aureus using the peptide RIP. Peptides 21: 1301-1311.

Balaban N, Goldkorn T, Gov Y, Hirshberg M, Koyfman N, Matthews HR, Nhan RT, Singh B, Uziel O (2001) Regulation of Staphylococcus aureus pathogenesis via target of RNAIII-activating Protein (TRAP). J Biol Chem 276: 2658-2667.

Balaban N, Goldkorn T, Nhan RT, Dang LB, Scott S, Ridgley RM, Rasooly A, Wright SC, Larrick JW, Rasooly R, Carlson JR (1998) Autoinducer of virulence as a target for vaccine and therapy against Staphylococcus aureus. Science 280: 438-440.

Balaban N, Gov Y, Bitler A, Boelaert JR (2003) Prevention of Staphylococcus aureus biofilm on dialysis catheters and adherence to human cells. Kidney Int 63: 340-345.

Benfield T, Espersen F, Frimodt-Moller N, Jensen AG, Larsen AR, Pallesen LV, Skov R, Westh H, Skinhoj P (2007) Increasing incidence but decreasing in-hospital mortality of adult Staphylococcus aureus bacteraemia between 1981 and 2000. Clin Microbiol Infect 13: 257-263.

Benincasa M, Skerlavaj B, Gennaro R, Pellegrini A, Zanetti M (2003) In vitro and in vivo antimicrobial activity of two alpha-helical cathelicidin peptides and of their synthetic analogs. Peptides 24: 1723-1731.

Bexfield A, Nigam Y, Thomas S, Ratcliffe NA (2004) Detection and partial characterisation of two antibacterial factors from the excretions/secretions of the medicinal maggot Lucilia sericata and their activity against methicillin-resistant Staphylococcus aureus (MRSA). Microbes Infect 6: 1297-1304.

Bisland SK, Chien C, Wilson BC, Burch S (2006) Pre-clinical in vitro and in vivo studies to examine the potential use of photodynamic therapy in the treatment of osteomyelitis. Photochem Photobiol Sci 5: 31-38.

Brady RA, Leid JG, Camper AK, Costerton JW, Shirtliff ME (2006) Identification of Staphylococcus aureus proteins recognized by the antibody-mediated immune response to a biofilm infection. Infect Immun 74: 3415-3426.

Brouillette E, Lacasse P, Shkreta L, Belanger J, Grondin G, Diarra MS, Fournier S, Talbot BG (2002) DNA immunization against the clumping factor A (ClfA) of Staphylococcus aureus. Vaccine 20: 23482357.

Browatzki M, Borst MM, Katus HA, Kranzhofer R (2006) Purulent pericarditis and pleural empyema due to Staphylococcus aureus septicemia. Int J Cardiol 107: 117-118.

Brown EL, Dumitrescu O, Thomas D, Badiou C, Koers EM, Choudhury P, Vazquez V, Etienne J, Lina G, Vandenesch F, Bowden MG (2009) The Panton-Valentine leukocidin vaccine protects mice against lung and skin infections caused by Staphylococcus aureus USA300. Clin Microbiol Infect 15: 156-164.

Brunel JM, Salmi C, Loncle C, Vidal N, Letourneux Y (2005) Squalamine: a polyvalent drug of the future? Curr Cancer Drug Targets 5: $267-272$.

Bubeck WJ, Schneewind O (2008) Vaccine protection against Staphylococcus aureus pneumonia. I Exp Med 205: 287-294.

Budzynska A, Rozalski M, Karolczak W, Wieckowska-Szakiel M, Sadowska B, Rozalska B (2011) Synthetic 3-arylideneflavanones as inhibitors of the initial stages of biofilm formation by Staphylococcus aureus and Enterococcus faecalis. Z Naturforsch C 66: 104-114.

Burkatovskaya M, Castano AP, midova-Rice TN, Tegos GP, Hamblin MR (2008) Effect of chitosan acetate bandage on wound healing in infected and noninfected wounds in mice. Wound Repair Regen 16: 425-431.

Capparelli R, Parlato M, Borriello G, Salvatore P, Iannelli D (2007) Experimental phage therapy against Staphylococcus aureus in mice. Antimicrob Agents Chemother 51: 2765-2773.

Chaillou LL, Nazareno MA (2009) Chemical variability in propolis from Santiago del Estero, Argentina, related to the arboreal environment as the sources of resins. J Sci Food Agric 89: 978-983. 
Chang BS, Moon JS, Kang HM, Kim YI, Lee HK, Kim JD, Lee BS, Koo HC, Park YH (2008) Protective effects of recombinant staphylococcal enterotoxin type $C$ mutant vaccine against experimental bovine infection by a strain of Staphylococcus aureus isolated from subclinical mastitis in dairy cattle. V accine 26: 2081-2091.

Chesi G, Colli A, Mestres CA, Gambarati G, Boni F, Gherli T (2006) Multiresistant-MRSA tricuspid valve infective endocarditis with ancient osteomyelitis locus. BMC Infect Dis 6: 124.

Cheung AL, Bayer AS, Zhang G, Gresham H, Xiong YQ (2004) Regulation of virulence determinants in vitro and in vivo in Staphylococcus aureus. FEMS Immunol Med Microbiol 40: 1-9.

Chi CY, Wang SM, Lin HC, Liu CC (2006) A clinical and microbiological comparison of Staphylococcus aureus toxic shock and scalded skin syndromes in children. Clin Infect Dis 42: 181-185.

Chi W, Qin C, Zeng L, Li W, Wang W (2007) Microbiocidal activity of chitosan-N-2-hydroxypropyl trimethyl ammonium chloride. I Appl Polymer Sci 103: 3851-3856.

Chin JN, Rybak MJ, Cheung CM, Savage PB (2007) Antimicrobial activities of ceragenins against clinical isolates of resistant Staphylococcus aureus. Antimicrob Agents Chemother 51: 1268-1273.

Cirioni O, Giacometti A, Ghiselli R, Bergnach C, Orlando F, Mocchegiani F, Silvestri C, Licci A, Skerlavaj B, Zanetti M, Saba V, Scalise G (2006a) Pre-treatment of central venous catheters with the cathelicidin BMAP-28 enhances the efficacy of antistaphylococcal agents in the treatment of experimental catheter-related infection. Peptides 27: 2104-2110.

Cirioni O, Giacometti A, Ghiselli R, Dell'Acqua G, Orlando F, Mocchegiani F, Silvestri C, Licci A, Saba V, Scalise G, Balaban N (2006b) RNAIII-inhibiting peptide significantly reduces bacterial load and enhances the effect of antibiotics in the treatment of central venous catheter-associated Staphylococcus aureus infections. I Infect Dis 193: 180-186.

Collins F, Hampton S (2005) Hand-washing and methicillin-resistant Staphylococcus aureus. Br J Nurs 14: 703-707.

Collins RJ (2007) Community-acquired methicillin-resistant Staphylococcus aureus in a group home setting. Consult Pharm 22: 763-767.

Conceicao T, ires-de-Sousa M, Fuzi M, Toth A, Paszti J, Ungvari E, van Leeuwen WB, van BA, Grundmann H, de LH (2007) Replacement of methicillin-resistant Staphylococcus aureus clones in Hungary over time: a 10-year surveillance study. Clin Microbiol Infect 13: 971979 .

Cushnie TP, Lamb AJ (2011) Recent advances in understanding the antibacterial properties of flavonoids. Int J Antimicrob Agents 38: 99-107.

Dajcs JJ, Thibodeaux BA, Girgis DO, Shaffer MD, Delvisco SM, O'Callaghan RJ (2002) Immunity to lysostaphin and its therapeutic value for ocular MRSA infections in the rabbit. Invest Ophthalmol Vis Sci 43: 3712-3716.

Davis JS (2005) Management of bone and joint infections due to Staphylococcus aureus. Intern Med J 35 (Suppl 2): S79-S96.

De KM, Doeschate KT, Dicks LM (2009) Nisin F in the treatment of respiratory tract infections caused by Staphylococcus aureus. Lett Appl Microbiol 48: 65-70.

Del Pozo JL, Alonso M, Arciola CR, Gonzalez R, Leiva J, Lasa I, Penades J (2007) Biotechnological war against biofilms. Could phages mean the end of device-related infections? Int J Artif Organs 30: 805-812.

DeLeo FR, Otto M, Kreiswirth BN, Chambers HF (2010) Community-associated meticillin-resistant Staphylococcus aureus. Lancet 375 : 1557-1568.

Dell'Acqua G, Giacometti A, Cirioni O, Ghiselli R, Saba V, Scalise G, Gov Y, Balaban N (2004) Suppression of drug-resistant Staphylococcal Infections by the quorum-sensing inhibitor RNAIII-inhibiting peptide. I Infect Dis 190: 318-320.

Deresinski S (2006) Antistaphylococcal vaccines and immunoglobulins: current status and future prospects. Drugs 66: 1797-1806.

Desachy A, Lina G, Vignon P, Hashemzadeh A, Denis F, Etienne J, Francois B, Ploy MC (2007) Role of superantigenic strains in the prognosis of community-acquired methicillin-susceptible Staphylococcus aureus bacteraemia. Clin Microbiol Infect 13: 1131-1133.

Dzwonkowska J, Kurlenda J, Baczkowski B, Mazurkiewicz S, Uzunov I, Ziolkowski W, Markowicz A (2007) The effect of antibiotic therapy on the incidence of Staphylococcus aureus infections in orthopaedic patients. Ortop Traumatol Rehabil 9: 532-547.

Embleton ML, Nair SP, Heywood W, Menon DC, Cookson BD, Wilson M (2005) Development of a novel targeting system for lethal photosensitization of antibiotic-resistant strains of Stapbylococcus aureus. Antimicrob Agents Chemother 49: 3690-3696.

Fattom A, Fuller S, Propst M, Winston S, Muenz L, He D, Naso R, Horwith G (2004) Safety and immunogenicity of a booster dose of Staphylococcus aureus types 5 and 8 capsular polysaccharide conjugate vaccine (StaphVAX) in hemodialysis patients. Vaccine 23: 656-663.

Feng Y, Chen CJ, Su LH, Hu S, Yu J, Chiu CH (2008) Evolution and pathogenesis of Staphylococcus aureus: lessons learned from genotyping and comparative genomics. FEMS Microbiol Rev 32: 23-37.
Field D, Connor PM, Cotter PD, Hill C, Ross RP (2008) The generation of nisin variants with enhanced activity against specific grampositive pathogens. Mol Microbiol 69: 218-230.

Filipowicz N, Kaminski M, Kurlenda J, Asztemborska M, Ochocka JR (2003) Antibacterial and antifungal activity of juniper berry oil and its selected components. Phytother Res 17: 227-231.

Finch R (2006) Gram-positive infections: lessons learnt and novel solutions. Clin Microbiol Infect 12: 3-8.

Fowler VG, Jr., Justice A, Moore C, Benjamin DK, Jr., Woods CW, Campbell S, Reller LB, Corey GR, Day NP, Peacock SJ (2005a) Risk factors for hematogenous complications of intravascular catheter-associated Staphylococcus aureus bacteremia. Clin Infect Dis 40: 695-703.

Fowler VG, Jr., Miro JM, Hoen B, Cabell CH, Abrutyn E, Rubinstein E, Corey GR, Spelman D, Bradley SF, Barsic B, Pappas PA, Anstrom KJ, Wray D, Fortes CQ, Anguera I, Athan E, Jones P, van der Meer JT, Elliott TS, Levine DP, Bayer AS (2005b) Staphylococcus aureus endocarditis: a consequence of medical progress. IAMA 293: 3012-3021.

Fraga CG, Galleano M, Verstraeten SV, Oteiza PI (2010) Basic biochemical mechanisms behind the health benefits of polyphenols. Mol Aspects Med 31: 435-445.

Francis JS, Doherty MC, Lopatin U, Johnston CP, Sinha G, Ross T, Cai M, Hansel NN, Perl T, Ticehurst JR, Carroll K, Thomas DL, Nuermberger E, Bartlett JG (2005) Severe community-onset pneumonia in healthy adults caused by methicillin-resistant Staphylococcus aureus carrying the Panton-Valentine leukocidin genes. Clin Infect Dis 40: $100-107$.

Gaudreau MC, Lacasse P, Talbot BG (2007) Protective immune responses to a multi-gene DNA vaccine against Staphylococcus aureus. Vaccine 25: 814-824.

Ghiselli R, Giacometti A, Cirioni O, Mocchegiani F, Silvestri C, Orlando F, Kamysz W, Licci A, Nadolski P, Della VA, Lukasiak J, Scalise G, Saba V (2007) Pretreatment with the protegrin IB-367 affects Gram-positive biofilm and enhances the therapeutic efficacy of linezolid in animal models of central venous catheter infection. JPEN J Parenter Enteral Nutr 31: 463-468.

Giacometti A, Cirioni O, Barchiesi F, Scalise G (2000) In-vitro activity and killing effect of polycationic peptides on methicillin-resistant Staphylococcus aureus and interactions with clinically used antibiotics. Diagn Microbiol Infect Dis 38: 115-118.

Giacometti A, Cirioni O, Ghiselli R, Bergnach C, Orlando F, D'Amato G, Mocchegiani F, Silvestri C, Del Prete MS, Skerlavaj B, Saba V, Zanetti M, Scalise G (2004) The antimicrobial peptide BMAP-28 reduces lethality in mouse models of staphylococcal sepsis. Crit Care Med 32: 2485-2490.

Giacometti A, Cirioni O, Ghiselli R, Orlando F, Silvestri C, Ranzone G, Testa I, Mocchegiani F, Della VA, Saba V, Scaloni A, Scalise $G$ (2006) Distinctin improves the efficacies of glycopeptides and betalactams against staphylococcal biofilm in an experimental model of central venous catheter infection. J Biomed Mater Res A 81A: 233-239.

Gilbert B, Robbins P, Livornese LL, Jr. (2011) Use of antibacterial agents in renal failure. Med Clin North Am 95: 677-702, vii.

Goldstein F (2007) The potential clinical impact of low-level antibiotic resistance in Staphylococcus aureus. I Antimicrob Chemother 59: 1-4.

Gonlugur U, Akkurt I, Ozdemir L, Bakici MZ, Icagasioglu S, Gultekin F (2003) Antibiotic susceptibility patterns of respiratory isolates of Staphylococcus aureus in a Turkish university hospital. Acta Microbiol Pol 52: 143-148.

Gorski A, Targonska M, Borysowski J, Weber-Dabrowska B (2009) The potential of phage therapy in bacterial infections of the eye. Ophthalmologica 223: 162-165.

Gottlieb GS, Fowler VG, Jr., Kong LK, McClelland RS, Gopal AK, Marr KA, Li J, Sexton DJ, Glower D, Corey GR (2000) Staphylococcus aureus bacteremia in the surgical patient: a prospective analysis of 73 postoperative patients who developed Staphylococcus aureus bacteremia at a tertiary care facility. $J$ Am Coll Surg 190: 50-57.

Gravet A, Couppie P, Meunier O, Clyti E, Moreau B, Pradinaud R, Monteil H, Prevost G (2001) Staphylococcus aureus isolated in cases of impetigo produces both epidermolysin A or B and LukE-LukD in $78 \%$ of 131 retrospective and prospective cases. J Clin Microbiol 39: 4349-4356.

Grinholc M, Kawiak A, Kurlenda J, Graczyk A, Bielawski KP (2008a) Photodynamic effect of protoporphyrin diarginate (PPArg2) on methicillin-resistant Staphylococcus aureus and human dermal fibroblasts. Acta Biochim Pol 55: 85-90.

Grinholc M, Szramka B, Kurlenda J, Graczyk A, Bielawski KP (2008b) Bactericidal effect of photodynamic inactivation against methicillinresistant and methicillin-susceptible Staphylococcus aureus is strain-dependent. I Photochem Photobiol B 90: 57-63.

Grinholc M, Szramka B, Olender K, Graczyk A (2007a) Bactericidal effect of photodynamic therapy against methicillin-resistant Staphylococcus aureus strain with the use of various porphyrin photosensitizers. Acta Biochim Pol 54: 665-670. 
Grinholc M, Wegrzyn G, Kurlenda J (2007b) Evaluation of biofilm production and prevalence of the icaD gene in methicillin-resistant and methicillin-susceptible Staphylococcus aureus strains isolated from patients with nosocomial infections and carriers. FEMS Immunol Med Microbiol 50: 375-379.

Hamblin MR, Hasan T (2004) Photodynamic therapy: a new antimicrobial approach to infectious disease? Photochem Photobiol Sci 3: 436-450.

Hamblin MR, O'Donnell DA, Murthy N, Rajagopalan K, Michaud N, Sherwood ME, Hasan T (2002) Polycationic photosensitizer conjugates: effects of chain length and Gram classification on the photodynamic inactivation of bacteria. I Antimicrob Chemother 49: 941-951.

Harraghy N, Kerdudou S, Herrmann M (2007) Quorum-sensing systems in staphylococci as therapeutic targets. Anal Bioanal Chem 387: 437-444.

Healy CM, Palazzi DL, Edwards MS, Campbell JR, Baker CJ (2004) Features of invasive staphylococcal disease in neonates. Pediatrics 114: 953-961.

Hiemstra PS, Fernie-King BA, McMichael J, Lachmann PJ, Sallenave JM (2004) Antimicrobial peptides: mediators of innate immunity as templates for the development of novel anti-infective and immune therapeutics. Curr Pharm Des 10: 2891-2905.

Hiramatsu K, Hanaki H, Ino T, Yabuta K, Oguri T, Tenover FC (1997) Methicillin-resistant Staphylococcus aureus clinical strain with reduced vancomycin susceptibility. I Antimicrob Chemother 40: 135-136.

Hong H, Landauer MR, Foriska MA, Ledney GD (2006) Antibacterial activity of the soy isoflavone genistein. J Basic Microbiol 46: 329-335.

Hu DL, Omoe K, Narita K, Cui JC, Shinagawa K, Nakane A (2006) Intranasal vaccination with a double mutant of staphylococcal enterotoxin $\mathrm{C}$ provides protection against Staphylococcus aureus infection. Microbes Infect 8: 2841-2848.

Huang YH, Tseng SP, Hu JM, Tsai JC, Hsueh PR, Teng LJ (2007) Clonal spread of SCCmec type IV methicillin-resistant Staphylococcus aureus between community and hospital. Clin Microbiol Infect 13: $717-724$.

Hudson MC, Ramp WK, Frankenburg KP (1999) Staphylococcus aureus adhesion to bone matrix and bone-associated biomaterials. FEMS Microbiol Lett 173: 279-284.

Ito T, Hiramatsu K (2003) [MRSA (methicillin-resistant Staphylococcus aureus)]. Nippon Rinsho 61 (Suppl 3): 164-170.

Ito T, Katayama Y, Asada K, Mori N, Tsutsumimoto K, Tiensasitorn C, Hiramatsu K (2001) Structural comparison of three types of staphylococcal cassette chromosome mec integrated in the chromosome in methicillin-resistant Staphylococcus aureus. Antimicrob Agents Chemother 45: 1323-1336.

James PR (2001) Isolated pericardial empyema secondary to Staphylococcus aureus. Eur J Intern Med 12: 377-379.

Janiszewska J, Urbanczyk-Lipkowska Z (2006) Synthesis, antimicrobial activity and structural studies of low molecular mass lysine dendrimers. Acta Biochim Pol 53: 77-82.

Jarraud S, Mougel C, Thioulouse J, Lina G, Meugnier H, Forey F, Nesme X, Etienne J, Vandenesch F (2002) Relationships between Staphylococcus aureus genetic background, virulence factors, agr groups (alleles), and human disease. Infect Immun 70: 631-641.

Jin T, Bokarewa M, Tarkowski A (2005) Urokinase-type plasminogen activator, an endogenous antibiotic. I Infect Dis 192: 429-437.

Jori G, Brown SB (2004) Photosensitized inactivation of microorganisms. Photochem Photobiol Sci 3: 403-405.

Josefsson E, Hartford O, O’Brien L, Patti JM, Foster T (2001) Protection against experimental Staphylococcus aureus arthritis by vaccination with clumping factor $\mathrm{A}$, a novel virulence determinant. I Infect Dis 184: 1572-1580.

Kaiser AM, Schultsz C, Kruithof GJ, bets-Ossenkopp Y, Vandenbroucke-Grauls C (2004) Carriage of resistant microorganisms in repatriates from foreign hospitals to The Netherlands. Clin Microbiol Infect 10: 972-979.

Kalmeijer MD, van Nieuwland-Bollen E, Bogaers-Hofman D, de Baere GA (2000) Nasal carriage of Staphylococcus aureus is a major risk factor for surgical-site infections in orthopedic surgery. Infect Control Hosp Epidemiol 21: 319-323.

Kampf G, Meyer B, Goroncy-Bermes P (2003) Comparison of two test methods for the determination of sufficient antimicrobial activity of three commonly used alcohol-based hand rubs for hygienic hand disinfection. J Hosp Infect 55: 220-225.

Karchmer AW (2006) From theory to practice: resistance in Staphylococcus aureus and new treatments. Clin Microbiol Infect 12: 15-21.

Keilman VK (1979) Prevention of purulent complications in the combined treatment of open fractures of crus bones. Sov Med 52-55.

Kerro-Dego O, Prysliak T, Potter AA, Perez-Casal J (2006) DNAprotein immunization against the GapB and GapC proteins of a mastitis isolate of Staphylococcus aureus. Vet Immunol Immunopathol 113: 125-138.

Kilani-Jaziri S, Frachet V, Bhouri W, Ghedira K, Chekir-Ghedira L, Ronot X (2011) Flavones inhibit the proliferation of human tumor cancer cell lines by inducing apoptosis. Drug Chem Toxicol 35: 1-10.
Kokai-Kun JF, Walsh SM, Chanturiya T, Mond JJ (2003) Lysostaphin cream eradicates Staphylococcus aureus nasal colonization in a cotton rat model. Antimicrob Agents Chemother 47: 1589-1597.

Komerik N, Nakanishi H, MacRobert AJ, Henderson B, Speight P, Wilson M (2003) In vivo killing of Porphyromonas gingivalis by toluidine blue-mediated photosensitization in an animal model. Antimicrob Agents Chemother 47: 932-940.

Korem M, Sheoran AS, Gov Y, Tzipori S, Borovok I, Balaban N (2003) Characterization of RAP, a quorum sensing activator of Staphylococcus aureus. FEMS Microbiol Lett 223: 167-175.

Kowalski TJ, Berbari EF, Osmon DR (2005) Epidemiology, treatment, and prevention of community-acquired methicillin-resistant Staphylococcus aureus infections. Mayo Clin Proc 80: 1201-1207.

Kristiansen MM, Leandro C, Ordway D, Martins M, Viveiros M, Pacheco T, Molnar J, Kristiansen JE, Amaral L (2006) Thioridazine reduces resistance of methicillin-resistant Staphylococcus aureus by inhibiting a reserpine-sensitive efflux pump. In Vivo 20: 361-366.

Kruszewska D, Sahl HG, Bierbaum G, Pag U, Hynes SO, Ljungh A (2004) Mersacidin eradicates methicillin-resistant Staphylococcus aureus (MRSA) in a mouse rhinitis model. J Antimicrob Chemother 54: 648-653.

Kuint J, Barzilai A, Regev-Yochay G, Rubinstein E, Keller N, MaayanMetzger A (2007) Comparison of community-acquired methicillinresistant Staphylococcus aureus bacteremia to other staphylococcal species in a neonatal intensive care unit. Eur J Pediatr 166: 319-325.

Kuklin NA, Clark DJ, Secore S, Cook J, Cope LD, McNeely T, Noble L, Brown MJ, Zorman JK, Wang XM, Pancari G, Fan H, Isett K, Burgess B, Bryan J, Brownlow M, George H, Meinz M, Liddell ME, Kelly R, Schultz L, Montgomery D, Onishi J, Losada M, Martin M, Ebert T, Tan CY, Schofield TL, Nagy E, Meineke A, Joyce JG, Kurtz MB, Caulfield MJ, Jansen KU, McClements W, Anderson AS (2006) A novel Staphylococcus aureus vaccine: iron surface determinant $\mathrm{B}$ induces rapid antibody responses in rhesus macaques and specific increased survival in a murine S. aureus sepsis model. Infect Immun 74: 2215-2223.

Kurlenda J, Grinholc M, Jasek K, Wegrzyn G (2007) RAPD typing of methicillin-resistant Staphylococcus aureus: a 7-year experience in a Polish hospital. Med Sci Monit 13: MT13-MT18.

Kurlenda J, Grinholc M, Krzyszton-Russjan J, Wisniewska K (2009) Epidemiological investigation of nosocomial outbreak of staphylococcal skin diseases in neonatal ward. Antonie Van Leeuwenboek. [Epub ahead of print].

Ladhani S, Garbash M (2005) Staphylococcal skin infections in children: rational drug therapy recommendations. Paediatr Drugs 7: 77102.

Le T, I, Mariani-Kurkdjian P, Collignon A, Gravet A, Clermont O, Brahimi N, Gaudelus J, Aujard Y, Navarro J, Beaufils F, Bingen E (2001) Breast milk transmission of a Panton-Valentine leukocidinproducing Staphylococcus aureus strain causing infantile pneumonia. J Clin Microbiol 39: 728-729.

LeClaire RD, Hunt RE, Bavari S (2002) Protection against bacterial superantigen staphylococcal enterotoxin B by passive vaccination. Infect Immun 70: 2278-2281.

Leszczynski P, Weber-Dabrowska B, Kohutnicka M, Luczak M, Gorecki A, Gorski A (2006) Successful eradication of methicillin-resistant Staphylococcus aureus (MRSA) intestinal carrier status in a healthcare workerm - case report. Folia Microbiol (Praba) 51: 236-238.

Levy SB (2005) Antibiotic resistance-the problem intensifies. Adv Drug Deliv Rev 57: 1446-1450.

Lew DP, Waldvogel FA (2004) Osteomyelitis. Lancet 364: 369-379.

Lipovsky A, Nitzan Y, Friedmann H, Lubart R (2009) Sensitivity of Staphylococcus aureus strains to broadband visible light. Photochem Photobiol 85: 255-260.

Livermore DM (2006) Can beta-lactams be re-engineered to beat MRSA? Clin Microbiol Infect 12 (Suppl 2): 11-16.

Maia GL, Falcao-Silva VS, Aquino PG, de Araujo-Junior JX, Tavares JF, da Silva MS, Rodrigues LC, de Siqueira-Junior JP, Barbosa-Filho JM (2011) Flavonoids from Praxelis clematidea R.M. King and Robinson modulate bacterial drug resistance. Molecules 16: 4828-4835.

Maira-Litran T, Kropec A, Goldmann D, Pier GB (2004) Biologic properties and vaccine potential of the staphylococcal poly- $N$-acetyl glucosamine surface polysaccharide. V accine 22: 872-879.

Maira-Litran T, Kropec A, Goldmann DA, Pier GB (2005) Comparative opsonic and protective activities of Staphylococcus aureus conjugate vaccines containing native or deacetylated Staphylococcal Poly$N$-acetyl-beta-(1-6)-glucosamine. Infect Immun 73: 6752-6762.

Maisch T, Bosl C, Szeimies RM, Lehn N, Abels C (2005) Photodynamic effects of novel XF porphyrin derivatives on prokaryotic and eukaryotic cells. Antimicrob Agents Chemother 49: 1542-1552.

Matsuzaki S, Yasuda M, Nishikawa H, Kuroda M, Ujihara T, Shuin T, Shen Y, Jin Z, Fujimoto S, Nasimuzzaman MD, Wakiguchi H, Sugihara S, Sugiura T, Koda S, Muraoka A, Imai S (2003) Experimental protection of mice against lethal Staphylococcus aureus infection by novel bacteriophage phi MR11. I Infect Dis 187: 613-624.

McKenney D, Pouliot KL, Wang Y, Murthy V, Ulrich M, Doring G, Lee JC, Goldmann DA, Pier GB (1999) Broadly protective vaccine 
for Staphylococcus aureus based on an in vivo-expressed antigen. Science 284: 1523-1527.

Menzies BE, Kourteva Y, Kaiser AB, Kernodle DS (2002) Inhibition of staphylococcal wound infection and potentiation of antibiotic prophylaxis by a recombinant fragment of the fibronectin-binding protein of Staphylococcus aureus. J Infect Dis 185: 937-943.

Mohr H, Redecker-Klein A (2003) Inactivation of pathogens in platelet concentrates by using a two-step procedure. Vox Sang 84: 96-104.

Moran GJ, Krishnadasan A, Gorwitz RJ, Fosheim GE, McDougal LK, Carey RB, Talan DA (2006) Methicillin-resistant S. aureus infections among patients in the emergency department. N Engl J Med 355: 666-674.

Murray RJ (2005) Recognition and management of Staphylococcus aureus toxin-mediated disease. Intern Med J 35 (Suppl 2): S106-S119.

Naffa RG, Bdour SM, Migdadi HM, Shehabi AA (2006) Enterotoxicity and genetic variation among clinical Staphylococcus aureus isolates in Jordan. J Med Microbiol 55: 183-187.

Narita K, Hu DL, Tsuji T, Nakane A (2008) Intranasal immunization of mutant toxic shock syndrome toxin 1 elicits systemic and mucosal immune response against Staphylococcus aureus infection. FEMS Immunol Med Microbiol 52: 389-396.

Nascimento JS, Ceotto H, Nascimento SB, Giambiagi-Demarval M, Santos KR, Bastos MC (2006) Bacteriocins as alternative agents for control of multiresistant staphylococcal strains. Lett Appl Microbiol 42: 215-221.

Nema V, Agrawal R, Kamboj DV, Goel AK, Singh L (2007) Isolation and characterization of heat resistant enterotoxigenic Staphylococcus aureus from a food poisoning outbreak in Indian subcontinent. Int J Food Microbiol 117: 29-35.

Nowakowska M, Jarosz-Chobot P, Polanska J, Machnica L (2007) Bacterial strains colonizing subcutaneous catheters of personal insulin pumps. Pol J Microbiol 56: 239-243.

Oh I, Yang WY, Chung SC, Kim TY, Oh KB, Shin J (2011) In vitro sortase A inhibitory and antimicrobial activity of flavonoids isolated from the roots of Sophora flavescens. Arch Pharm Res 34: 217-222.

Oh S, Kim SH, Ko Y, Sim JH, Kim KS, Lee SH, Park S, Kim YJ (2006) Effect of bacteriocin produced by Lactococcus sp. HY 449 on skin-inflammatory bacteria. Food Chem Toxicol 44: 1184-1190.

Omoe K, Ishikawa M, Shimoda Y, Hu DL, Ueda S, Shinagawa K (2002) Detection of seg, seh, and sei genes in Staphylococcus aureus isolates and determination of the enterotoxin productivities of $\mathrm{S}$. aureus isolates Harboring seg, seh, or sei genes. J Clin Microbiol 40: $857-862$.

Onlen Y, Duran N, Atik E, Savas L, Altug E, Yakan S, Aslantas O (2007) Antibacterial activity of propolis against MRSA and synergism with topical mupirocin. J Altern Complement Med 13: 713-718.

Otto M (2008) Targeted immunotherapy for staphylococcal infections : focus on anti-MSCRAMM antibodies. BioDrugs 22: 27-36.

Ozcelik B, Kartal M, Orhan I (2011) Cytotoxicity, antiviral and antimicrobial activities of alkaloids, flavonoids, and phenolic acids. Pharm Biol 49: 396-402.

Parfitt T (2005) Georgia: an unlikely stronghold for bacteriophage therapy. Lancet 365: 2166-2167.

Pei L (2004) New approaches to develop anti-staphylococcal agents. Curr Med Chem -Anti Inf Agents 267-278.

Peloi LS, Soares RR, Biondo CE, Souza VR, Hioka N, Kimura E (2008) Photodynamic effect of light-emitting diode light on cell growth inhibition induced by methylene blue. J Biosci 33: 231-237.

Perez MM, Prenafeta A, Valle J, Penades J, Rota C, Solano C, Marco J, Grillo MJ, Lasa I, Irache JM, Maira-Litran T, Jimenez-Barbero J, Costa L, Pier GB, de AD, Amorena B (2009) Protection from Staphylococcus aureus mastitis associated with poly-N-acetyl beta-1,6 glucosamine specific antibody production using biofilm-embedded bacteria. Vaccine 27: 2379-2386.

Peschel A (2002) How do bacteria resist human antimicrobial peptides? Trends Microbiol 10: 179-186.

Peschel A, Collins LV (2001) Staphylococcal resistance to antimicrobial peptides of mammalian and bacterial origin. Peptides 22: 1651-1659.

Plata K, Rosato AE, Wegrzyn G (2009) Staphylococcus aureus as an infectious agent: overview of biochemistry and molecular genetics of its pathogenicity. Acta Biochim Pol 56: 597-612.

Priest DH, Peacock JE, Jr. (2005) Hematogenous vertebral osteomyelitis due to Staphylococcus aureus in the adult: clinical features and therapeutic outcomes. South Med J 98: 854-862.

Rayner C, Munckhof WJ (2005) Antibiotics currently used in the treatment of infections caused by Staphylococcus aureus. Intern Med J 35 (Suppl 2): S3-16.

Regev-Yochay G, Rubinstein E, Barzilai A, Carmeli Y, Kuint J, Etienne J, Blech M, Smollen G, Maayan-Metzger A, Leavitt A, Rahav G, Keller N (2005) Methicillin-resistant Staphylococcus aureus in neonatal intensive care unit. Emerg Infect Dis 11: 453-456.

Rennermalm A, Li YH, Bohaufs L, Jarstrand C, Brauner A, Brennan FR, Flock JI (2001) Antibodies against a truncated Staphylococcus aureus fibronectin-binding protein protect against dissemination of infection in the rat. Vacine 19: 3376-3383.
Richards RG, Harris LG, Schneider E, Haas N (2006) Antiseptics and antibiotics on implants. Int J Care Injured 37: 113-116.

Roberts S, Chambers S (2005) Diagnosis and management of Staphylococcus aureus infections of the skin and soft tissue. Intern Med J 35 (Suppl 2): S97-105.

Romanov VP, Lebedev LR, Tereshchenko TA, Nazarikova NI, Masycheva VI (2001) [Photoinactivation of microorganisms in the presence of photosensitizers]. Zh Mikrobiol Epidemiol Immunobiol 24-26.

Romanova NA, Brovko LY, Moore L, Pometun E, Savitsky AP, Ugarova NN, Griffiths MW (2003) Assessment of photodynamic destruction of Escherichia coli $\mathrm{O} 157: \mathrm{H} 7$ and Listeria monocytogenes by using ATP bioluminescence. Appl Environ Microbiol 69: 6393-6398.

Runarsson O, Holappa J, Nevalainen T, Hjalmarsdottir M, Jarvinen T, Loftsson T, Einarsson JM, Jonsdottir S, Valdimarsdottir M, Masson M (2007) Antibacterial activity of methylated chitosan and chitooligomer derivatives: synthesis and structure activity relationships. Eur Polymer J 43: 2660-2671.

Sadowska B, Cochard T, Poutrel B, Pytlos M, Bonar A, Gatkowska J, Rudnicka W, Polak J, Bielecki S, Siwinska-Gol bH, Rozalska B (2001) Characterization of Staphylococcus aureus strains isolated from cystic fibrosis patients by conventional and molecular typing. Acta Microbiol Pol 50: 251-261.

Salmi C, Loncle C, Vidal N, Laget M, Letourneux Y, Brunel JM (2008a) New 3-aminosteroid derivatives as a new family of topical antibacterial agents active against methicillin-resistant Staphylococcus aureus (MRSA). Lett Drug Design Disc 5: 169-172.

Salmi C, Loncle C, Vidal N, Letourneux Y, Brunel JM (2008b) New stereoselective titanium reductive amination synthesis of 3 -amino and polyaminosterol derivatives possessing antimicrobial activities. Eur J Med Chem 43: 540-547.

Sandhu K, Kanwar AJ (2004) Generalized bullous impetigo in a neonate. Pediatr Dermatol 21: 667-669.

Sandrini MP, Shannon O, Clausen AR, Bjorck L, Piskur J (2007) Deoxyribonucleoside kinases activate nucleoside antibiotics in severely pathogenic bacteria. Antimicrob Agents Chemother 51: 2726-2732.

Savas L, Duran N, Onlen Y, Savas N, Erayman M (2005) Prospective analysis of antibiotic susceptibility patterns of MRSA in a Turkish University Hospital. Turk J Med Sci 35: 323-327.

Schaffer AC, Lee JC (2008) Vaccination and passive immunisation against Staphylococcus aureus. Int J Antimicrob Agents 32 (Suppl 1): S71S78.

Seifert H, Wisplinghoff H, Schnabel P, von EC (2003) Small colony variants of Staphylococcus aureus and pacemaker-related infection. Emerg Infect Dis 9: 1316-1318.

Senna JP, Roth DM, Oliveira JS, Machado DC, Santos DS (2003) Protective immune response against methicillin resistant Staphylococcus aureus in a murine model using a DNA vaccine approach. Vaccine 21: $2661-2666$.

Severina E, Severin A, Tomasz A (1998) Antibacterial efficacy of nisin against multidrug-resistant Gram-positive pathogens. J Antimicrob Chemother 41: 341-347.

Sforcin JM, Bankova V (2011) Propolis: is there a potential for the development of new drugs? I Ethnopharmacol 133: 253-260.

Shannon O, Uekotter A, Flock JI (2006) The neutralizing effects of hyperimmune antibodies against extracellular fibrinogen-binding protein, Efb, from Staphylococcus aureus. Scand J Immunol 63: 184-190.

Sharma M, Visai L, Bragheri F, Cristiani I, Gupta PK, Speziale P (2008) Toluidine blue-mediated photodynamic effects on staphylococcal biofilms. Antimicrob Agents Chemother 52: 299-305.

Shinefield HR (2006) Use of a conjugate polysaccharide vaccine in the prevention of invasive staphylococcal disease: is an additional vaccine needed or possible? Vaccine 24 Suppl 2: S2-S9.

Simonetti O, Cirioni O, Ghiselli R, Goteri G, Scalise A, Orlando F, Silvestri C, Riva A, Saba V, Madanahally KD, Offidani A, Balaban N, Scalise G, Giacometti A (2008) RNAIII-inhibiting peptide enhances healing of wounds infected with methicillin-resistant Staphylococcus aureus. Antimicrob Agents Chemother 52: 2205-2211.

Slopek S, Weber-Dabrowska B, Dabrowski M, Kucharewicz-Krukowska A (1987) Results of bacteriophage treatment of suppurative bacterial infections in the years 1981-1986. Arch Immunol Ther Exp (Warsz) 35: 569-583.

Smeltzer MS, Gillaspy AF (2000) Molecular pathogenesis of staphylcoccal osteomyelitis. Poult Sci 79: 1042-1049.

Sola C, Gribaudo G, Vindel A, Patrito L, Bocco JL (2002) Identification of a novel methicillin-resistant Staphylococcus aureus epidemic clone in Cordoba, Argentina, involved in nosocomial infections. J Clin Microbiol 40: 1427-1435.

Soncin M, Fabris C, Busetti A, Dei D, Nistri D, Roncucci G, Jori G (2002) Approaches to selectivity in the $\mathrm{Zn}(\mathrm{II})$-phthalocyanine-photosensitized inactivation of wild-type and antibiotic-resistant Staphylococcus aureus. Photochem Photobiol Sci 1: 815-819.

Soukos NS, Ximenez-Fyvie LA, Hamblin MR, Socransky SS, Hasan T (1998) Targeted antimicrobial photochemotherapy. Antimicrob Agents Chemother 42: 2595-2601.

Spanu T, Romano L, D'Inzeo T, Masucci L, Albanese A, Papacci F, Marchese E, Sanguinetti M, Fadda G (2005) Recurrent ventriculop- 
eritoneal shunt infection caused by small-colony variants of Staphylococcus aureus. Clin Infect Dis 41: e48-e52.

Stranger-Jones YK, Bae T, Schneewind O (2006) Vaccine assembly from surface proteins of Staphylococcus aureus. Proc Natl Acad Sci US A 103: 16942-16947.

Stryjewski ME, Hall RP, Chu VH, Kanafani ZA, O'Riordan WD, Weinstock MS, Stienecker RS, Streilein R, Dorschner RA, Fowler VG, Jr., Corey GR, Gallo RL (2007) Expression of antimicrobial peptides in the normal and involved skin of patients with infective cellulitis. J Infect Dis 196: 1425-1430.

Sulakvelidze A, Alavidze Z, Morris JG, Jr. (2001) Bacteriophage therapy. Antimicrob Agents Chemother 45: 649-659.

Svetoch EA, Levchuk VP, Pokhilenko VD, Eruslanov BV, Mitsevich EV, Mitsevich IP, Perelygin VV, Stepanshin YG, Stern NJ (2008) Inactivating methicillin-resistant Staphylococcus aureus and other pathogens by use of bacteriocins OR-7 and E 50-52. J Clin Microbiol 46: 3863-3865.

Tacconelli E (2006) New strategies to identify patients harbouring antibiotic-resistant bacteria at hospital admission. Clin Microbiol Infect 12: 102-109.

Tajima Y (2005) Polyoxotungstates reduce the beta-lactam resistance of methicillin-resistant Staphylococcus aureus. Mini Rev Med Chem 5: 255-268.

Thanacoody HK (2007) Thioridazine: resurrection as an antimicrobial agent? Br J Clin Pharmacol 64: 566-574.

Therrien R, Lacasse P, Grondin G, Talbot BG (2007) Lack of protection of mice against Staphylococcus aureus despite a significant immune response to immunization with a DNA vaccine encoding collagenbinding protein. Vaccine 25: 5053-5061.

Trampuz A, Zimmerli W (2006) Antimicrobial agents in orthopaedic surgery: Prophylaxis and treatment. Drugs 66: 1089-1105.

Vayalumkal JV, Jadavji T (2006) Children hospitalized with skin and soft tissue infections: a guide to antibacterial selection and treatment. Paediatr Drugs 8: 99-111.

Verbeken G, De VD, Vaneechoutte M, Merabishvili M, Zizi M, Pirnay JP (2007) European regulatory conundrum of phage therapy. Future Microbiol 2: 485-491.
Verdrengh M, Collins LV, Bergin P, Tarkowski A (2004) Phytoestrogen genistein as an anti-staphylococcal agent. Microbes Infect 6: 86-92.

Wang Q, Wang H, Xie M (2010) Antibacterial mechanism of soybean isoflavone on Staphylococcus aureus. Arch Microbiol 192: 893-898.

Whyte D, Monahan R, Boyle L, Slevin B, FitzGerald R, Barron D, De FJ, Kelleher K (2005) The incidence of $S$. aureus bacteraemia in acute hospitals of the Mid-Western Area, Ireland, 2002-2004. Euro Surveill 10: 75-77.

Wills QF, Kerrigan C, Soothill JS (2005) Experimental bacteriophage protection against Staphylococcus aureus abscesses in a rabbit model. Antimicrob Agents Chemother 49: 1220-1221.

Wilson M (2004) Lethal photosensitisation of oral bacteria and its potential application in the photodynamic therapy of oral infections. Photochem Photobiol Sci 3: 412-418.

Witte W, Pasemann B, Cuny C (2007) Detection of low-level oxacillin resistance in mecA-positive Staphylococcus aureus. Clin Microbiol Infect 13: 408-412.

Yacoby I, Bar H, Benhar I (2007) Targeted drug-carrying bacteriophages as antibacterial nanomedicines. Antimicrob Agents Chemother 51: 2156-2163.

Yang XP, Li EW, Zhang Q, Yuan CS, Jia ZJ (2006) Five new iridoids from Patrinia rupestris. Chem Biodivers 3: 762-770.

Yin S, Fan CQ, Wang Y, Dong L, Yue JM (2004) Antibacterial prenylflavone derivatives from Psoralea corylifolia, and their structureactivity relationship study. Bioorg Med Chem 12: 4387-4392.

Zanetti M, Gennaro R, Skerlavaj B, Tomasinsig L, Circo R (2002) Cathelicidin peptides as candidates for a novel class of antimicrobials. Curr Pharm Des 8: 779-793.

Zeina B, Greenman J, Corry D, Purcell WM (2002) Cytotoxic effects of antimicrobial photodynamic therapy on keratinocytes in vitro. $\mathrm{Br}$ J Dermatol 146: 568-573.

Zeina B, Greenman J, Corry D, Purcell WM (2003) Antimicrobial photodynamic therapy: assessment of genotoxic effects on keratinocytes in vitro. BrJ Dermatol 148: 229-232.

Zhou H, Xiong ZY, Li HP, Zheng YL, Jiang YQ (2006) An immunogenicity study of a newly fusion protein Cna-FnBP vaccinated against Staphylococcus aureus infections in a mice model. Vaccine 24: 4830-4837. 